CHOROIDAL HEMANGIOMA TREATMENT

\title{
ANALYSIS OF LONG TERM OUTCOMES OF RADIOTHERAPY AND VERTEPORFIN \\ PHOTODYNAMIC THERAPY FOR CIRCUMSCRIBED CHOROIDAL HEMANGIOMA
}

Vasilios P. Papastefanou MD, PhD ${ }^{1}$, P. Nicholas Plowman FRCR ${ }^{2}$, Ehud Reich MD ${ }^{1}$,

Efthymia Pavlidou MD ${ }^{1}$, Marie Restori, PhD, ${ }^{3}$ John L. Hungerford FRCOphth ${ }^{1}$, Amit K.

Arora MBBS, FRCOphth ${ }^{1}$, Victoria ML Cohen MB BChir, FRCOphth ${ }^{1}$, Mandeep S. Sagoo MB, PhD, FRCS (Ed) $)^{1,4}$

${ }^{1}$ Ocular Oncology Service, St Bartholomew`s Hospital and Moorfields Eye Hospital, London,

UK

${ }^{2}$ Department of Radiation Oncology, St. Bartholomew`s Hospital, London, UK

${ }^{3}$ Ultrasound Department, Moorfields Eye Hospital, London, UK

${ }^{4}$ UCL Institute of Ophthalmology, London, UK

Corresponding Author:

Vasilios P. Papastefanou MD, PhD

Moorfields Eye Hospital

Email: vasilios.papastefanou@moorfields.nhs.uk

Tel: +4402072533411

Financial support:None

No conflicting relationship exists for any author

Running header: Choroidal hemangioma treatment

Supplemental material is available at www.aaojournal.org. 


\section{PURPOSE}

2 To determine the long-term therapeutic outcome for different treatments of circumscribed

3 choroidal hemangioma ( $\mathrm{CCH}$ )

4 DESIGN

Retrospective observational study

\section{SUBJECTS}

Patients with newly diagnosed $\mathrm{CCH}$

\section{METHODS/INTERVENTION}

Observation, visudyne photodynamic therapy (PDT), lens-sparing external beam radiotherapy (LS-EBRT) or plaque brachytherapy

\section{MAIN OUTCOME MEASURES}

Best-corrected visual acuity (BCVA) at baseline and throughout follow-up, tumor dimensions and OCT central thickness (where available) at baseline and throughout followup were recorded.

\section{RESULTS}

There were 60 treatment-naïve consecutive cases with $\mathrm{CCH}$ during the period January 2000 to June 2014; 42 (70\%) received treatment. These were LS-EBRT (23/60, 38\%, mean follow-up 45.5 months), PDT (16/60, 27\%, 38 months), plaque radiotherapy (3/60, 5\%, 92 months). Macular location, mottled or orange pigment and absence of drusen were significantly more frequent in the treatment group.

In the LS-EBRT group, median thickness reduction on ultrasound B scan was $1.6 \mathrm{~mm}$ (mean, $1.65 \pm 1.6$ range, $-6.5-+0.7$ ). BCVA gain was $0.22 \pm 0.34$, with $>3$ Snellen lines in $48 \%$ of cases. Kaplan-Meier estimates were $80 \%$ for any gain and $40 \%$ for $>3$ Snellen lines gain at 5 years.

In the PDT group, median thickness reduction was $0.95 \mathrm{~mm}(1 \pm 0.8,-2.5-+0.2)$. BCVA gain was at $0.3 \pm 0.51$, with $>3$ Snellen lines in $30 \%$ of cases. Kaplan-Meier estimates were $93 \%$ for any gain and $68 \%$ for $>3$ Snellen lines at 5 years. Double versus single duration PDT had more favorable outcomes with a greater reduction in tumor thickness $(p=0.04)$, central retinal thickness $(p=0.02)$ and improvement in visual acuity (median 0.33 vs -0.05 ). There was no significant difference in tumor thickness reduction or BCVA gain between LSEBRT and PDT. 
With plaque brachytherapy, mean thickness reduction was $2.5 \mathrm{~mm}$, but BCVA loss of

$33>2$ Snellen lines was noted in all three cases at end of follow up. Radiation complications

34 developed in 10/23 (43.5\%) cases from the LS-EBRT group and $2 / 3$ (87\%) cases from the 35 plaque brachytherapy group.

36 CONCLUSION

37 LS-EBRT is equivalent to PDT in CCH management for post-treatment BCVA and tumor

38 thickness reduction. The risk of LS-EBRT and plaque brachytherapy was late radiation-related

39 complications. Double-duration PDT was more favorable than single duration. 
Introduction

42 Circumscribed choroidal hemangioma $(\mathrm{CCH})$ is a vascular tumor of the choroid composed of 43 endothelium-lined vascular channels occupying the choroid up to its full thickness. ${ }^{1}$ It is 44 almost always unifocal and unilateral and develops usually between the second and fourth decade of life. Its pathogenesis is unknown. The tumor is often overlooked on routine eye examination or is misdiagnosed. The differential diagnosis of circumscribed choroidal hemangioma includes highly vascular amelanotic melanoma, early choroidal osteoma, and orange-coloured metastases such as thyroid, renal, and neuroendocrine carcinoma. ${ }^{2}$ The presence of an associated detachment needs to be differentiated from central serous retinopathy, exudative age-related macular degeneration and posterior scleritis. ${ }^{3}$

These lesions are often asymptomatic, though symptoms can occur as a direct function of the tumor location or behaviour ${ }^{1,2}$. Subfoveal tumors can induce unilateral hypermetropic shift as a result of anterior displacement of the retina ${ }^{4}$. Juxta- or parafoveal tumors cause vision loss if associated with exudative subretinal fluid or retinoschisis

A variety of modalitites has been used for the treatment of these lesions aiming principally at reduction of leakage and secondly at regression of the lesion. Laser photocoagulation, 5-8 external beam radiation therapy, ${ }^{9-11}$ stereotactic radiotherapy, ${ }^{12-14}$ proton beam radiotherapy, ${ }^{15-17}$ plaque radiotherapy, ${ }^{11,18-20}$ transpupillary thermotherapy, ${ }^{21-23}$ and more recently photodynamic therapy with verteporfin have been used ${ }^{24-25}$ The aim of this retrospective study is to determine the long term therapeutic outcome for different treatments of circumscribed choroidal hemangioma $(\mathrm{CCH})$.

\section{Patients and methods}

This was a retrospective observational study of referred CCH cases from January 2000 to June 2014. Institutional Review Board (IRB)/Ethics Committee approval was obtained (SAGM1003s) from Moorfields Eye Hospital and the research adhered to the tenets of the 
70

71

72

73

74

75

76

77

78

79

80

81

82

83

84

85

86

87

88

89

90

91

92

93

94

95

96

97

98

99

blurred vision. All patients underwent full ophthalmic examination, B-scan ultrasonography (Sequoia, Siemens, Erlangen, Germany), fluorescein and indocyanine green angiography as required. Spectral-domain optical coherence tomography (Spectralis, Heidelberg, Germany and Topcon, Tokyo, Japan) scans were used during the study period, when available and as required. Doppler B-scan ultrasonography was examined where available (Sequoia, Siemens, Erlangen, Germany),

Data collected included patient demographics (age, sex, presenting symptom), visual acuity (decimal scale and Snellen lines), tumor features (height, maximal diameter, associated clinical findings). B-ultrasonography and Spectral-domain optical coherence tomography. OCT measurements were obtained from the automated software and manual measurements as needed in order to avoid discrepancy because of the different software platforms. Visual acuity was assessed during the study before, throughout treatment and at final follow up. Analysis of vision change was subdivided in to any visual gain, $\geq 2$ snellen visual acuity line gain, $\geq 3$ snellen visual acuity line gain, any visual acuity loss, $\geq 2$ snellen visual acuity lines loss, $\geq 3$ snellen visual acuity lines loss.

The indication for treatment was the presence of symptoms, including blurred vision, photopsiae, or hyperopic shift and if there was fluid at the fovea or worsening subretinal fluid threatening the fovea. Patients requiring treatment were offered lens-sparing external beam radiotherapy (LS-EBRT), verteporfin photodynamic therapy (PDT) or plaque radiotherapy. All patients received these as first line treatment. The non-treatment group consisted of patients that did not require treatment during the follow up period.

Studies in the literature were identified by a systematic search using Medline (http://www.ncbi.nlm.nih.gov/pubmed). Terms searched were as follows: "choroidal hemangioma" along with "photodynamic therapy", "external beam radiotherapy," and "plaque brachytherapy". In reports referring to treatment of choroidal hemangiomas with photodynamic therapy published results on protocol settings, lesion thickness and visual 
100 acuity outcomes were collected and analysed. Visual acuity outcomes presented were

101 converted to the decimal scale for analysis purposes.

102

103

104 Lens-sparing external beam radiotherapy (LS-EBRT)

105 LS-EBRT was provided with the Varian Eclipse 6MV linear accelerator following CT and mapping of the lesion (isodose curves in grays) with the appropriate software (Aria). The axial mid-ocular/lens CT section was chosen for the planning and isodosimetry calculated such that the lens received less than $10 \%$ of the prescribed dose. A prescription dose of $40 \mathrm{~Gy}$ was delivered in 20 fractions ( $2 \mathrm{GY}$ per fraction) over 28 days.

\section{Photodynamic Therapy with Verteporfin (PDT)}

112 Photodynamic therapy (Activis, Quantel Medical, Cournon d'Auvergne, France) with 113 Verteporfin (Visudyne; Novartis Ophthalmics, Basel, Switzerland) was performed with a 114 single spot covering the lesion using Area Centralis lens or Quadraspheric lens (Volk, Mentor, $115 \mathrm{OH}$, USA) based on lesion size. Photodynamic therapy-treated cases were subcategorized 116 based on laser application settings. Treatment parameters were for standard $50 \mathrm{~J} / \mathrm{cm}^{2}$

117 fluence, $600 \mathrm{~mW} / \mathrm{cm}^{3}$ light dose, and single $(83 \mathrm{sec}$ ) or double (166 sec) duration.

\section{Plaque brachytherapy}

120 Plaque brachytherapy using ruthenium applicators (Bebig, Berlin, Germany) was performed 121 in some patients. A prescription dose of 40-50 Gy at the lesion apex was prescribed and 122 duration varied from $1 \mathrm{~d} 1 \mathrm{hr}$ to $4 \mathrm{~d} 2 \mathrm{hrs}$ due to specific activity of the source and height of the 123 tumor.

\section{Efficacy and Safety}

126 Efficacy of different treatment modalities was determined by best corrected visual acuity 127 (BCVA) (decimal scale and conversion to Snellen lines for statistical analysis purposes), height 128 on B-scan $(\mathrm{mm})$ and OCT central retinal thickness change $(\mu \mathrm{m})$ at the end of follow up period. 129 Radiation retinopathy and other complications of treatment were recorded. 


\section{Statistical analysis}

132 Descriptive statistical analysis, with $\mathrm{x}^{2}$ and non-parametric Mann-Whitney tests, was used to 133 evaluate the findings following prior Kolmogorov-Smirnov tests indicating the presence of non-normal distribution of the results. Kaplan-Meier survival analysis was performed for the endpoints of any visual gain, $\geq 2$ snellen visual acuity line gain, $\geq 3$ snellen visual acuity line gain, any visual acuity loss, $\geq 2$ snellen visual acuity lines loss, $\geq 3$ snellen visual acuity lines loss and resolution of fluid at the end of follow-up period. Cumulative probability was recorded and statistical significance of survival curves was assessed with log-rank test. A difference of 0.05 was considered statistically significant.

141 Collected data from previous studies were analysed with descriptive statistics, ANOVA and ttest. A difference of 0.05 was considered statistically significant. Analysis was done with SPSS v.11 (IBM Corp, NY, USA)

\section{$\underline{\text { Results }}$}

147 There were 60 consecutive cases of $\mathrm{CCH}$ included in the study. The median age at presentation was 61.5 years (mean \pm SD , $58 \pm 15$ - range, $18-87$ ) with $51 \%$ male and $49 \%$ female patients. Tumors were located in the macula in 59\% (35/60), juxtapapillary in $25 \%(15 / 60)$ and peripheral (outside the retinal vascular arcades) in 17\% (10/60). Patient demographics and tumor features are summarised in Table 1.

At baseline, the median tumor height was at $2.6 \mathrm{~mm}(2.7 \pm 1,1-6.6)$ and median maximal diameter was at $7 \mathrm{~mm}(7 . \pm 2.7,2.5-16.3)$. Subretinal fluid was present on clinical examination in 46/60 patients (77\%). OCT scan was available in 28 patients and median central retinal subfield thickness was $335 \mu \mathrm{m}(418 \pm 250,208-1200)$. Internal blood flow of tumors at baseline was available in 13 cases. Median internal blood flow was $22 \mathrm{~cm} / \mathrm{s}$ 157 (21.5 $\pm 9.7,4-45)$.

\section{Treatment vs non-treatment group}

160 Out of 60 eyes with $\mathrm{CCH}, 42$ received treatment (70\%). The median follow up after treatment was 47 months $(49 \pm 11,2-144)$. The remaining $30 \%$ (18/60) consisted of the non-treatment group. Median follow up for the non-treatment group was 27.5 months (42 $\pm 21,5-156)$. 
164 Comparison of tumor dimensions and features between groups are presented in Table 2. In 165 our cohort, hemangiomas with macular location $\left(p-0.001, x^{2}\right)$, mottled $\left(p=0.03, x^{2}\right)$ or orange pigment $\left(p=0.008, x^{2}\right)$ and absence of drusen $\left(p=0.003, x^{2}\right)$ were significantly more frequent

167 in the treatment group. In addition, tumor height at baseline was significantly higher in the 168 treatment group at baseline at $2.7(2.9 \pm 1,1.5-6.6) \mathrm{mm}$ vs non-treatment group at 2.0 169 (2.2 $\pm 1,1-4.7),(p=0.018$, Mann-Whitney).

170

\section{Treatment modalities}

172 There were $38 \%$ (23/60) of eyes that were managed with LS-EBRT (20 fractions), 27\% (16/60) 173 received PDT (14/16 received one session only, 1/16 with two sessions 84 months apart and $1741 / 16$ with three sessions at 8 months and 32 months ) and 5\% (3/60) patients were treated 175 with plaque brachytherapy. Median follow up for LS-EBRT cases was 30.8 months (mean 176 45.5 \pm 30 , range 5-143), for PDT 24 months (mean, $38.6 \pm 32.6$, range 2-93) and for plaque 177 brachytherapy 79 months (mean $92 \pm 28$, range $72-125$ ).

178

179 With regard to tumor location, 66\% (10/15) of juxtapapillary tumours were treated with LS180 EBRT and the remainder did not receive any treatment. For macular tumors, 40\% (14/35) 181 were treated with PDT, 29\% (10/35) with LS-EBRT, 8\% (3/27) with plaque brachytherapy whereas $23 \%(8 / 35)$ did not require any treatment. For peripheral tumors, $50 \%(5 / 10)$ required treatment, LS-EBRT in 3 cases and PDT in 2 cases.

\section{Tumor dimensions}

\section{Thickness}

188 The median reduction in tumor thickness in the LS-EBRT group was $1.6 \mathrm{~mm}$ (mean, $1.65 \pm 1.6$ 189 range, -6.5- +0.7); With photodynamic therapy was -0.95 (mean, $1 \pm 0.8$ range, $-2.5-+0.2$ ) and 190 for plaque brachytherapy was at $2.7 \mathrm{~mm}$ (mean, $2.5 \pm 0.8$ range, $-3,2--1.6)$. There was no 191 significant difference in tumor thickness reduction between LS-EBRT and PDT ( $p=0.177)$. In 192 the non-treatment group the tumor thickness reduced by a median of $0.25 \mathrm{~mm}$ (mean, 0.01 $193 \pm 0.8$ range, $-1.7-+1.5)$. In all treatment groups compared to non-treatment, there was a 194 significant reduction in thickness. 
197 On ultrasound B scan measurements, the median MBD reduction in the LS-EBRT group was 198 at $-1.8 \mathrm{~mm}$ (mean, $-2.26 \pm 2.5$, range $-8.1-+1.5$ ); with photodynamic therapy was $-0.15 \mathrm{~mm}$ 199 (mean, $-0.8 \pm 2.3$, range $-5.2-+3.7$ ) and with plaque radiotherapy was at $-4.3 \mathrm{~mm}$ (mean $2003.7 \pm 2.4$, range $-5.8--1$ ). There was a statistically significant difference in MBD reduction between LS-EBRT and PDT $(p=0.044)$. In the non-treatment group median tumor MBD reduction on was at $0 \mathrm{~mm}$ (mean, $-0.25 \pm 2$, range $-5.2-+3$ ) (Figure 1). Compared to the nontreatment group, there was a significant difference in MBD in the LS-EBRT group $(p=0.003)$ and the plaque radiotherapy group $(p=0.017)$, but not in the photodynamic therapy group $(p=0.422)$. (Figure 2A-D).

\section{Visual acuity outcomes}

\section{Treatment subgroups}

210 At the end of follow up period visual acuity gain was significant in LS-EBRT $(p=0.008)$ and PDT

$211(p=0.014)$ in comparison to plaque brachytherapy though there was no significant difference 212 between PDT and LS-EBRT ( $p=0.94$, Mann-Whitney). In particular, visual gain $>2$ Snellen lines 213 was noted in $52 \%$ of cases with LS-EBRT and in $50 \%$ of cases with PDT $\left(p=0.576, x^{2}\right)$ and visual 214 gain $>3$ Snellen lines was noted in $47.8 \%$ of cases with LS-EBRT vs $25 \%$ of cases with PDT $215\left(p=0.15, x^{2}\right)$. Loss of $>2$ Snellen lines was noted in all three cases which underwent plaque 216 brachytherapy with two cases demonstrating considerable visual loss (>3 Snellen lines) (Table $2173)$.

Kaplan-Meier analysis

\section{Visual acuity gain (Figure 3A-C)}

221 For patients with CCH undergoing LS-EBRT, Kaplan-Meier estimates for visual acuity gain by 22212 months were $70 \%$ for any gain, $45 \%$ for $>2$ Snellen line gain and $30 \%$ for $>3$ Snellen line 223 gain. By 5 years the corresponding estimates were $80 \%$ for any gain, $45 \%$ for $>2$ Snellen line 224 gain and $40 \%$ for $>3$ Snellen line gain. 
226 For patients who underwent PDT, Kaplan Meier estimates by 12 months were at 75\% for any 227 gain, $57 \%$ for $>2$ Snellen line gain and $30 \%$ for $>3$ Snellen line VA gain. By 5 years the 228 corresponding estimates were $93 \%$ for any gain, $65 \%$ for $>2$ Snellen line gain and $68 \%$ for $>3$ 229 Snellen line gain.

230

231 Despite these differences no statistical significance was noted between curves for PDT and 232 LS-EBRT ( $p=0.24$ for any gain, 0.3 for $>2$ Snellen line gain and 0.34 for $>3$ Snellen line gain, log233 rank test)

235 Comparing the observation group versus treatment with either LS-EBRT or PDT, a significant 236 difference was found for any gain and $>2$ Snellen line gain. In addition a significant difference 237 was noted between observation group and PDT group for $>3$ Snellen line gain $(p=0.014, \log$ 238 rank test)

Visual acuity loss (Figure 3D-F)

241 For patients with CCH undergoing LS-EBRT Kaplan-Meier estimates for visual acuity loss by 12 242 months were $17 \%$ for any loss and $5 \%$ for $>2$ Snellen line VA loss or $>3$ Snellen line VA loss. By 2435 years the corresponding estimates were 33\% for any loss, $17 \%$ for $>2$ Snellen line visual 244 acuity loss but $30 \%$ for $>3$ Snellen line visual acuity loss.

For patients who underwent PDT, Kaplan Meier estimates by 12 months were at $14 \%$ for any loss and $9 \%$ for $>2$ or $>3$ Snellen line loss. By 5 years, the corresponding estimates were at $32 \%$ for any loss and $38 \%$ for $>2$ and $>3$ Snellen line loss.

Despite these differences, no statistical significance was noted between curves for PDT and LS-EBRT in each endpoint ( $p=0.95$ for any loss, 0.32 for $>2$ Snellen line loss and 0.23 for $>3$ Snellen line visual loss, log-rank test) groups in Table 4.

\section{Non treatment group}


In this group, a mild visual acuity improvement of $0.08 \pm 0.13$ was noted by the end of follow up period with the majority of cases $11 / 18$ (61\%) not demonstrating any change in visual acuity.

\section{Central Retinal Thickness and Resolution of Fluid on Optical Coherence Tomography}

OCT scans of the macula were available in 21 cases (7 in the LS-EBRT group and 14 in the PDT group). Median CRT reduction in the LS-EBRT group was $-63 \mu \mathrm{m}$ (mean $-233 \pm 397$, range -1085 -26) and median CRT reduction in the PDT group was at $-87.5 \mu \mathrm{m}$ (mean $-99 \pm 184$, range -391 - +341). Despite these differences there was no significant difference between LS-EBRT and PDT central retinal thickness reduction at the end of follow up $(p=0.9)$

Resolution of fluid on OCT at the end of follow up period was noted in 4/7 (57.1\%) cases in the LS-EBRT group and in 9/14 (64.3\%) cases in the PDT group (Figure 4). There was no significant difference between groups $\left(p=0.554, x^{2}\right)$.

273

\section{Photodynamic therapy - Subgroup analysis}

In the subgroup of patients receiving PDT treatment $(n=16), 5 / 16$ received single duration PDT, 9/16 received double duration PDT and 2/16 received both. The latter were excluded from this subgroup analysis. (Table 5)

Median visual acuity was reduced by 0.05 in the single duration group and improved by 0.33 in the double duration group, though this difference failed to reach statistical significance ( $p=1.9$, Mann-Whitney). However, any visual acuity gain was noted in $2 / 5$ cases (40\%) in the single duration group and in all 9 cases (100\%) in the double duration group. Amongst this, visual gain $>3$ Snellen lines occurred in $1 / 5$ cases (25\%) for single duration and in $3 / 9$ cases (33\%) of the double duration group.

Tumor thickness was significantly reduced in the double duration subgroup $(p=0.042)$.(Table

5) (Figure 4) No significant difference was noted with regards to MBD change at the end of duration group compared to the single duration group $(p=0.018)$ (Table 5). 


\section{Complications}

292 Radiation related complications occurred in 10/23 (43.5\%) cases in the LS-EBRT group and 2/3 293 (67\%) cases from the plaque brachytherapy (Table 6). Radiation retinopathy changes included 294 localized retinal hemorrhage and exudation, cotton wool spots and even radiation 295 maculopathy requiring intravitreal bevacizumab treatment (Figure 2E-F). One case developed persistent lid edema that was treated conservatively. In the LS-EBRT group radiation related complications were manifest at an average of 33.3 months after treatment ( $95 \% \mathrm{Cl} 16.6-49.9)$. Plaque brachytherapy complications occurred at 13 and 56 months respectively after treatment (Figure 5). No complications were noted in the PDT treatment group, notably no severe vision loss, choroidal ischaemia or retinal vascular occlusion.

\section{DISCUSSION}

304 Circumscribed choroidal hemangiomas are benign vascular tumors of the choroid, which are often overlooked, but have characteristic ultrasound and angiographic appearance. Treatment is indicated if a $\mathrm{CCH}$ is causing visual symptoms or is imminently at risk of causing vision loss (retinal detachment, scotoma or hyperopic shift). ${ }^{1-2,4}$ The optimal treatment has yet to be established. In this report, we retrospectively reviewed the long-term outcomes of consecutive cases in a period spanning 14 years. This included both observation and treatment groups, using lens-sparing external beam radiotherapy (LS-EBRT), photodynamic therapy (PDT) and plaque radiotherapy.

313 An overall comparison of the clinical features of tumors between the treatment versus no 314 treatment groups yielded some interesting findings. The thickness of hemangiomas requiring treatment was significantly higher at $2.7 \mathrm{~mm}$ versus $2.0 \mathrm{~mm}$, despite no difference in the maximal basal diameter. As expected, tumors located in the macular area were more likely to require treatment. Orange or yellow tumor color was not a factor but the presence of mottled or orange pigment on the tumours was significantly higher in tumors requiring treatment. The lack of drusen at presentation was also significantly higher in treated tumors, indicating that these changes imply chronicity. 
323 LS-EBRT has been used in the past for the treatment of circumscribed choroidal hemangioma 9-11,26 with cumulative dose ranging from 18-30 Gy. The exact mechanism of the radiation effect on circumscribed choroidal hemangioma is unknown as there are no histologic descriptions or systematic studies ${ }^{10}$

LS-EBRT giving 40 Gy in 20 fractions over 28 days, without any other treatment, was used in 23 cases in our study with a median follow up 30.8 months. In our cases, $43 \%$ of tumors were juxtafoveal, $43 \%$ juxtapapillary and $13 \%$ were peripheral. In other studies the treatment parameters varied. Schilling et al. ${ }^{10}$ reported the long-term outcomes of $20 \mathrm{~Gy}$ in 10 fractions LS-EBRT in 36 eyes with CCH with a median follow up of 4 years. In that series, $64 \%$ of tumors were juxtafoveal and the remainder extrafoveal. Adjuvant treatment with laser photocoagulation was administered either before or after EBRT in 9 cases. Ritland et al. ${ }^{9}$ gave a cumulative dose of $20 \mathrm{~Gy}$ or $24 \mathrm{~Gy}$ in 10 or fewer fractions in 9 cases, with follow up from 0.4 to 8.8 years. Madreperla et al ${ }^{11}$ treated two patients with a cumulative dose of $18 \mathrm{~Gy}$ and 30 Gy respectively in 10 and 20 fractions with a one-year follow up and Eide et al. ${ }^{27}$ administered 24Gy in 8 fractions in two cases, with a one and two-year follow up respectively.

In the current study, in the LS-EBRT cases, visual acuity improved in $52 \%$, was unchanged in $13 \%$ and $18 \%$ had significant vision loss. Survival analysis indicated an $88 \%$ probability of any visual gain and a $55 \%$ probability of any visual loss in 10 years. Schilling ${ }^{9}$ reported visual acuity improvement in $40 \%$, no change in $39 \%$ and decrease in $22 \%$. All other series reported

344 favorable visual acuity outcomes $9,11,27$. The higher dose of $40 \mathrm{~Gy}$ appears to have a greater 345 effect on retaining or improving vision.

Anatomic outcomes after LS-EBRT were also favorable. The mean tumor thickness reduced by $1.65 \mathrm{~mm}$ and maximal basal diameter by $2.25 \mathrm{~mm}$ and in cases where OCT was available, $60 \%$ of cases showed resolution of subretinal fluid. Schilling et al ${ }^{10}$ did not find any change in tumor thickness following LS-EBRT, which may account for their lower success rate from using a lower radiation dose. They did however, find complete resolution of subretinal fluid in $63.8 \%$ of cases and residual fluid distant to the fovea resolved in $36.2 \%$ cases. Other series 9 , 
355 We found mild non-proliferative radiation retinopathy that did not affect overall visual 356 prognosis in 10 eyes at an average of 33 months after treatment. One eye needed intravitreal bevacizumab treatment for radiation macular edema, likely as a result of our higher radiation dose. No side effects were noted in the other publications. ${ }^{9-11,27}$

\section{Photodynamic therapy}

Photodynamic therapy with verteporfin is a potent vaso-occlusive treatment, selectively generating intraluminal thrombosis at endothelial membranes within specific vascular beds, while sparing the adjacent retina and RPE-Bruch membrane complex. ${ }^{28}$ The selective treatment effect of PDT for vascular neoplasms and choroidal neovascularization was assumed to rely on an increased expression of low-density lipoprotein receptors in the rapidly proliferating vascular endothelial cells within these lesions as the sensitizers are coupled with specific carriers (antibodies, markers). ${ }^{28}$ Witschell and Font ${ }^{29}$ reported a histopathological study of 71 cases of $\mathrm{CCH}$, which revealed the vasculature of the $\mathrm{CCH}$ to be mature, without proliferation of endothelial cells or abnormalities of the endothelial basement membrane in all cases. Although $\mathrm{CCH}$ is composed of capillary or cavernous vessels with a normal endothelial lining, it is suggested that the localized effect of PDT on CCH may also be driven by the distinctively slower perfusion characteristics of these tumors. ${ }^{24}$ This theory was further supported by fluorescein and indocyanine green angiography testing that showed intensive and persistent occlusion of the collateral choroid circulation after PDT ${ }^{30}$.

In the literature so far, there are 38 studies including 12 case reports in which PDT has been used as monotherapy in 267 cases and in combination with other modalities in 30 cases adding up to a total of 297 cases. (Table 7) There is variable follow up in these cases with a median of 14.5 months (mean 23.52 .1 months, range 0.6-67 months). In our study, PDT subgroup follow up was a median of 24 months.

In publications on PDT, tumour location has been reported for a total of 282 cases: the vast majority of these (94\%) were in the macula or close to the optic nerve (subfoveal 97/282; juxtafoveal 39/282; extrafoveal $71 / 282$; and juxtapapillary $57 / 282$ ). In our study only $2 / 15$ 
384 of the laser can be avoided if the lesion is abutting to the optic disc, as complications can adversely affect the visual outcome 24,25

The infusion of the photosensitizer varies in different reports. (Table 7) The standard protocol for CNV treatment administers the infusion over 10 minutes (with an added 5 minutes before laser activation) or as a bolus infusion over 1 minute to reduce washout. ${ }^{24}$ We treated the cases reported herein using the 10 minute protocol with 5 added minutes before laser activation.

The number of PDT treatments for $\mathrm{CCH}$ has also been variable. (Table 7) The indication for retreatment in prior studies was persistent subretinal exudation or residual tumor prominence seen ophthalmoscopically and documented by ultrasonography 6 weeks after the first treatment ${ }^{14}$ with recurrence of symptoms or foveal edema ${ }^{31}$ In our study treatment was discontinued when there was no evidence of subretinal fluid. Angiographically, $\mathrm{CCH}$ treated with PDT demonstrates areas within the tumor showing non-perfusion, reduced leakage, and finally focal choroidal atrophy. ${ }^{24}$ The risk of continuing PDT beyond symptomatic relief is tissue ischemia or destruction. ${ }^{30,32}$ Though PDT can be repeated up to 4 times, judgement needs to be exercised in order to cease treatment when visual gain is maximal. In publications on PDT, $71 \%$ of cases (212/297) were treated with a single session of PDT. In the 15 cases reported in this study, 11 had one PDT session but 4 cases required more than 1 session (maximum 3 ) at a time interval between 3 months to 7 years.

PDT laser settings reported in the literature have varied considerably with respect to laser power, fluence and duration, with the commonest settings the same as for choroidal neovascularisation in age-related macular degeneration. The standard settings of $50 \mathrm{~J} / \mathrm{cm}$ power, $600 \mathrm{~mW} / \mathrm{cm}^{2}$ fluence and 83 seconds duration were used in $60 \%$ of cases in the literature (177/297 patients). ${ }^{8,31,33-57}$ The duration of laser activation has been variable in the 410 literature, with treatments lasting $63^{32}, 113^{58}, 125^{31,57}$ and 166 seconds $25,45,48,54,59,60$. Of note there have been cases treated for 166 seconds that have received bolus infusion 25,48

412 whereas all other reports used standard infusion time of 10 minutes. 45, 54, 59, 60 Double laser 413 power of $100 \mathrm{~J} / \mathrm{cm}$ with full fluence $\left(600 \mathrm{~mW} / \mathrm{cm}^{2}\right)$ has been also used ${ }^{54,59-61}$. This was found 414 to be efficient for a re-treatment regimen for PDT for AMD and also selected because of 
415 increased thickness of the lesion. In another report the PDT parameters varied according to

416 the location, with standard AMD settings for foveal or juxtafoveal lesions, increased to 75

$417 \mathrm{~J} / \mathrm{cm}$ for extrafoveal lesions with duration of 125 seconds. ${ }^{31}$

418

419 In our study, using standard infusion and laser parameters, treatment was administered over 420 either 83 seconds or 166 seconds (double duration). Both time durations have been 421 previously used albeit double duration with greater power. ${ }^{44,54,59,60}$ The rationale for double 422 duration treatment is based on the slower blood perfusion through choroidal hemangiomas 423 as previously discussed ${ }^{24,28}$ We chose not to increase the power to avoid extensive choroidal 424 atrophy or ischemia.

425

426 In 267 previously published cases treated with PDT monotherapy the mean visual acuity was $4270.3 \pm 0.03$ before treatment and $0.479 \pm 0.04$ after treatment leading to an estimated 428 improvement in visual acuity by $0.186 \pm 0.027$. Comparative analysis for treatment settings 429 has demonstrated no significant difference in visual acuity difference for different settings 430 (ANOVA, $\mathrm{p}=0.266$ ). In those reports, standard PDT with double duration was not assessed. In 431 our study there was no significant difference in comparison of the literature to single duration 432 standard PDT but the difference was considerable with an improvement of visual acuity of 4330.33 with double duration standard PDT. An important note is that all conclusions from 434 subgroup analysis are restricted from the small sample size.

435 All different PDT protocols reported show a favorable decrease in tumour thickness, namely $436-2.1 \pm 0.1 \mathrm{~mm}$ in 260 cases. Comparing the effect of different settings there were 25 cases in 437 the literature with bolus infusion and double duration that had a mean thickness decrease of $438-3.2 \pm 0.2 \mathrm{~mm}$ and 48 cases with power $100 \mathrm{~J}$ and double duration presented with a mean thickness decrease of $-2.1 \pm 0.2$ when compared with 177 cases with standard PDT with AMD settings at $-1.9 \pm 0.1$; a statistically significant result (ANOVA, $p<0.001$ ). In our series this trend was also confirmed with a mean reduction in thickness at $-1.3 \pm 0.7$ for double duration PDT vs $-0.35 \pm 0.57$ for standard PDT (t-test, $p=0.042$ ). Similarly, OCT reduction in central retinal

443 thickness by $-184 \pm 131$ um vs $138 \pm 181$ um was also significant (t-test, $p=0.018$ ) Double 444 duration PDT therefore has a more favorable anatomic, as well as visual outcome to the thickness of the lesion and the central retinal thickness. 
447 No complications were found in our series, including rare complications following PDT such 448 as retinal neovascularization on the tumour surface, ${ }^{3,45}$ or polypoidal choroidal vasculopathy 44953

\section{Plaque radiotherapy}

452 Cobalt-60, ${ }^{18}$ iodine-125, ruthenium-106, ${ }^{11}$ iodine-125, ${ }^{19}$ and palladium-103 ${ }^{20}$ have all been used for treating circumscribed choroidal hemangiomas. Cobalt-60 applicators with apex dose of 40-60 Gy and base dose of 90-240 Gy in 38 patients with macula involving secondary exudative retinal detachments had a favorable response but 3 developed retinal vascular complications. ${ }^{18}$ Functional outcomes were worse in patients with subfoveal tumours. Madreperla et al. ${ }^{11}$ used plaque brachytherapy with $50 \mathrm{~Gy}$ to the tumour apex in 8 patients with $\mathrm{CCH}$ ( 2 with iodine-125 and six with ruthenium-106), showing that at 1 year 5/8 patients had an improved visual acuity of more than three lines. Complications were not reported in one-year follow up. López-Caballero et al ${ }^{19}$ used iodine-125 plaque brachtytherapy in 8 patients with a mean apical dose of $46.9 \mathrm{~Gy}$. Despite favorable anatomic response of the tumor and retinal detachment, there was a reduction in mean visual acuity due to radiation retinopathy, glaucoma or cataract by 30 months follow up. Aizman et al ${ }^{20}$ used Palladium103 plaque radiotherapy in 5 cases with a mean apical dose of 29Gy. By two years' visual acuity had improved, resorption of subretinal fluid was noted but one patient developed radiation retinopathy.

In our series, three patients received ruthenium-106 plaque brachytherapy with an apical dose of $40-50$ Gy with a mean follow up of 92 months. All cases demonstrated at least $>2$ Snellen line visual loss with two cases demonstrating $>3$ Snellen line visual acuity loss. Tumour thickness was improved in all cases. In one eye visual acuity loss was attributed to atrophic changes in the macular area whereas two cases developed radiation retinopathy at 13 and 56 months post treatment. Hence plaque brachytherapy has an initial favorable anatomic and

474 functional outcome but is associated with late radiation retinopathy in 2/3 cases in keeping 475 with other reports. Plaque brachytherapy should be reserved for cases resilient to other treatment options with poor visual prognosis. 
478 In this study we have presented our results of a retrospective series of circumscribed 479 choroidal hemangiomas with long-term follow up from a single centre, including a non480 treatment group, and compared the outcomes of different treatment modalities particularly 481 PDT and LS-EBRT with the literature.

482

483 We conclude that hemangiomas requiring treatment were significantly more elevated in 484 comparison to hemangiomas that require observation, were located in the macular area and 485 had mottled or orange pigment in their surface more frequently with lack of drusen. There was no significant difference between PDT and LS-EBRT either for visual acuity gain or for the 5-year probability of visual acuity gain. Similar outcomes were noted for visual acuity loss.

There was no significant difference between PDT and LS-EBRT in reduction of thickness of either the lesion itself or central retinal thickness or in resolution of fluid. LS-EBRT significantly reduced maximal basal diameter. Double duration PDT was significantly more successful in lesion thickness reduction in comparison to single duration, confirmed by the collective analysis of previously published cases treated with double duration protocols versus standard PDT settings.

LS-EBRT with a cumulative dose of $40 \mathrm{~Gy}$ is associated with favorable visual outcomes. There was an increased risk of long-term radiation related retinal complications which in the majority were not vision threatening. In our small number treated with ruthenium plaque radiotherapy, non-proliferative radiation retinopathy developed contributing to significant visual loss.

501

502 Based on the above, PDT, especially double duration has favorable anatomic and functional 503 outcomes for symptomatic circumscribed choroidal hemangiomas and LS-EBRT with a 504 cumulative dose of $40 \mathrm{~Gy}$ has comparable long-term outcomes despite minor radiation505 related complications. Plaque brachytherapy is associated with long term radiation related 506 complications and hence can be reserved for hemangiomas that do not involve the posterior 507 pole. 
CHOROIDAL HEMANGIOMA TREATMENT

509

510

511 
CHOROIDAL HEMANGIOMA TREATMENT

512

513

514

515

516

517

518

519

520

521

522

523

524

525

526

527

528

529

530

531

532

533

534

535

536

537

538

539

540

541

542

543

\section{REFERENCES}

1. Tsipursky MS, Golchet PR, Jampol LM. Photodynamic therapy of choroidal hemangioma in sturge-weber syndrome, with a review of treatments for diffuse and circumscribed choroidal hemangiomas. Surv Ophthalmol. 2011; 56: 68-85.

2. Shields CL, Honavar SG, Shields JA, Cater J, Demirci H. Circumscribed choroidal hemangioma: clinical manifestations and factors predictive of visual outcome in 200 consecutive cases. Ophthalmology. 2001; 108: 2237-48.

3. Agrawal R, Lavric A, Restori M, Pavesio C, Sagoo MS NODULAR_POSTERIOR_SCLERITIS: Clinico-Sonographic Characteristics and Proposed Diagnostic Criteria. Retina. 2016 Feb;36(2):392-401

4. Umazume K, Goto H, Kimura K, Kawakami S, Kasai K, Usui Y, Wakabayashi Y. Review of clinical features of circumscribed choroidal hemangioma in 28 cases. Nippon Ganka Gakkai Zasshi. 2011; 115: 454-9

5. Sanborn GE, Augsburger JJ, Shields JA. Treatment of circumscribed choroidal hemangiomas. Ophthalmology. 1982; 89: 1374-80.

6. Bottoni F, Tervaert DC, Deutman AF. Fluorescein angiographic findings and results of laser treatment in circumscribed choroidal hemangioma. Int Ophthalmol. 1990; 14: 259-65.

7. Lanzetta P, Virgili G, Ferrari E, Menchini U. Diode laser photocoagulation of choroidal hemangioma. Int Ophthalmol. 1995-1996; 19: 239-47.

8. Madreperla SA. Choroidal hemangioma treated with photodynamic therapy using verteporfin. Arch Ophthalmol. 2001; 119: 1606-10. 
9. Ritland JS, Eide N, Tausj $\varnothing$ J. External beam irradiation therapy for choroidal hemangiomas. Visual and anatomical results after a dose of 20 to 25 Gy. Acta Ophthalmol Scand. 2001; 79: 184-6

10. Schilling H, Sauerwein W, Lommatzsch A, Friedrichs W, Brylak S, Bornfeld N, Wessing A. Long-term results after low dose ocular irradiation for choroidal hemangiomas. $\mathrm{Br} J$ Ophthalmol. 1997; 81: 267-73

11. Madreperla SA, Hungerford JL, Plowman PN, Laganowski HC, Gregory PT. Choroidal hemangiomas: visual and anatomic results of treatment by photocoagulation or radiation therapy. Ophthalmology. 1997; 104: 1773-8

556

12. Kong DS, Lee JI, Kang SW.Gamma knife radiosurgery for choroidal hemangioma. Am J Ophthalmol. 2007; 144: 319-22.

559

13. Song WK, Byeon SH, Kim SS, Kwon OW, Lee SC.Gamma knife radiosurgery for choroidal hemangiomas with extensive exudative retinal detachment. $\mathrm{Br} J$ Ophthalmol. 2009; 93: 836-7

14. Kivelä $T$, Tenhunen $M$, Joensuu $T$, Tommila $P$, Joensuu $H$, Kouri M.Stereotactic radiotherapy of symptomatic circumscribed choroidal hemangiomas. Ophthalmology. 2003; 110: 1977-82.

15.Zografos L, Egger E, Bercher L, Chamot L, Munkel G Proton beam irradiation of 570

16. Hannouche D, Frau E, Desjardins L, Cassoux N, Habrand IL, Offret H.Efficacy of proton therapy in circumscribed choroidal hemangiomas associated with serious retinal detachment. Ophthalmology. 1997; 104: 1780-4. 


\section{CHOROIDAL HEMANGIOMA TREATMENT}

576

577

578

579

580

581

582

583

584

585

586

587

588

589

590

591

592

593

594

595

596

597

598

599

600

601

602

603

604

605

606

607
Desjardins L.Long-term results of low-dose proton beam therapy for circumscribed choroidal hemangiomas. Retina. 2009; 29: 170-5.

18. Zografos L, Bercher L, Chamot L, Gailloud C, Raimondi S, Egger E.Cobalt-60 treatment of choroidal hemangiomas. Am J Ophthalmol. 1996; 121: 190-9.

19. López-Caballero C, Saornil MA, De Frutos J, Bianciotto C, Muiños Y, Almaraz A, LópezLara F, Contreras I.High-dose iodine-125 episcleral brachytherapy for circumscribed choroidal hemangioma. Br J Ophthalmol. 2010; 94: 470-3

20. Aizman A, Finger PT, Shabto U, Szechter A, Berson A.Palladium 103 (103Pd) plaque radiation therapy for circumscribed choroidal hemangioma with retinal detachment. Arch Ophthalmol. 2004; 122: 1652-6

21. García-Arumí J, Ramsay LS, Guraya BC. Transpupillary thermotherapy for circumscribed choroidal hemangiomas. Ophthalmology. 2000; 107: 351-6

22. Fuchs AV, Mueller AJ, Grueterich M, Ulbig MW. Transpupillary thermotherapy (TTT) in circumscribed choroidal hemangioma. Graefes Arch Clin Exp Ophthalmol. 2002; 240: 7-11

23. Kamal A, Watts AR, Rennie IG. Indocyanine green enhanced transpupillary thermotherapy of circumscribed choroidal hemangioma. Eye (Lond). 2000; 14: 701-5.

24. Schmidt-Erfurth UM, Michels S, Kusserow C, Jurklies B, Augustin AJ. Photodynamic therapy for symptomatic choroidal hemangioma: visual and anatomic results. Ophthalmology. 2002; 109: 2284-94.

25. Michels S, Michels R, Simader C, Schmidt-Erfurth U. Verteporfin therapy for choroidal hemangioma: a long-term follow-up. Retina. 2005; 25: 697-703.

26. Plowman PN, Hungerford JL. Radiotherapy for ocular angiomas. Br J Ophthalmol. 1997; 
CHOROIDAL HEMANGIOMA TREATMENT

608

81: 258-9.

609

27. Eide N, Syrdalen P, Tausjø J, Tverå K.External radiotherapy for circumscribed choroidal hemangiomas using a modified retinoblastoma technique. Acta Ophthalmol Scand. 1995; 73: 547-50

613

28. Schmidt-Erfurth U, Hasan T, Gragoudas E, Michaud N, Flotte TJ, Birngruber R. Vascular targeting in photodynamic occlusion of subretinal vessels. Ophthalmology. 1994; 101: 1953-61.

617

29. Witschel H, Font RL. Hemangioma of the choroid. A clinicopathologic study of 71 cases and a review of the literature. Surv Ophthalmol. 1976; 20: 415-31

620

30. Schmidt-Erfurth U, Niemeyer M, Geitzenauer W, Michels S. Time course and morphology of vascular effects associated with photodynamic therapy. Ophthalmology. 2005; 112: 2061-9.

624

31. Liu W, Zhang Y, Xu G, Qian J, Jiang C, Li L.Optical coherence tomography for evaluation of photodynamic therapy in symptomatic circumscribed choroidal hemangioma. Retina. 2011; 31: 336-43

32. Chan LW, Hsieh YT. Photodynamic therapy for choroidal hemangioma unresponsive to ranibizumab. Optom Vis Sci. 2014; 91: e226-9

631

33. Andonegui J, Pérez de Arcelus M, Jiménez-Lasanta L.Treatment with photodynamic therapy of circumscribed choroidal hemangioma Arch Soc Esp Oftalmol. 2010; 85: 337-40.

635

34. Bazin L, Gambrelle J.Combined treatment with photodynamic therapy and intravitreal dexamethasone implant $\left(\operatorname{Ozurdex}\left({ }^{\oplus}\right)\right)$ for circumscribed choroidal hemangioma].J $\mathrm{Fr}$ 
640

641

642

643

644

645

646

647

648

649

650

651

652

653

654

655

656

657

658

659

660

661

662

663

664

665

666

667

668

669

670

671

35. Bhatt C, Bandyopadhyay SK, Chatterjee PK, Paul RC, Bagchi SC, Chatterjee A. Photodynamic therapy for circumscribed choroidal hemangioma: a case report. J Indian Med Assoc. 2011; 109: 759-61

36. Boixadera A, García-Arumí J, Martínez-Castillo V, Encinas JL, Elizalde J, Blanco-Mateos G, Caminal J, Capeans C, Armada F, Navea A, Olea JL. Prospective clinical trial evaluating the efficacy of photodynamic therapy for symptomatic circumscribed choroidal hemangioma. Ophthalmology. 2009; 116: 100-105

37. Bosch MM, Helbig H. Blackening of a choroidal hemangioma after photodynamic therapy. Klin Monbl Augenheilkd. 2005; 222: 258-60.

38. Chalam KV, Murthy RK, Gupta SK, Brar VS. Spectral domain optical coherence tomography guided photodynamic therapy for choroidal hemangioma: a case report. Cases J. 2009; 2: 8778

39. Elizalde J, Vasquez L, lyo F, Abengoechea S. Photodynamic therapy in the management of circumscribed choroidal hemangioma. Can J Ophthalmol. 2012; 47: 16-20.

40. Gupta M, Singh AD, Rundle PA, Rennie IG. Efficacy of photodynamic therapy in circumscribed choroidal hemangioma. Eye (Lond). 2004; 18: 139-42

41. Huang S, Fabian J, Murray T, Shi W. Symptomatic circumscribed choroidal hemangioma undergoing PDT: VA outcomes. Optom Vis Sci. 2009; 86: 286-9

42. Hussain N, Das T, Ram LS, Sumasri K. Persistent choroidal thickening despite photodynamic therapy for circumscribed choroidal hemangioma. Ophthalmic Surg Lasers Imaging. 2006; 37: 76-8.

43. Kubicka-Trzaska A, Romanowska-Dixon B. Photodynamic therapy of circumscribed choroidal hemangioma. Klin Oczna. 2006; 108(4-6):209-13. 


\section{CHOROIDAL HEMANGIOMA TREATMENT}

672

673

674

675

676

677

678

679

680

681

682

683

684

685

686

687

688

689

690

691

692

693

694

695

696

697

698

699

700

701

702

703

44. Landau IM, Steen B, Seregard S. Photodynamic therapy for circumscribed choroidal hemangioma. Acta Ophthalmol Scand. 2002; 80: 531-6.

45. Leys AM, Silva R, Inhoffen W, Tatar O. Neovascular growth following photodynamic therapy for choroidal hemangioma and neovascular regression after intravitreous injection of triamcinolone. Retina. 2006; 26: 693-7.

46. López-Quero MC, Casas-Fernández A, Lucas-Elío G, Rodríguez-González-Herrero ME, Marín-Sánchez JM. [Circumscribed choroidal hemangioma treated with photodynamic therapy]. Arch Soc Esp Oftalmol. 2008;83: 553-7

47. Nicolò M, Ghiglione D, Polizzi A, Calabria G. Choroidal hemangioma treated with photodynamic therapy using verteporfin: report of a case. Eur J Ophthalmol. 2003; 13: 656-61

48. Pilotto E, Urban F, Parrozzani R, Midena E. Standard versus bolus photodynamic therapy in circumscribed choroidal hemangioma: functional outcomes. Eur J Ophthalmol. 2011; 21: 452-8

49. Robertson DM. Photodynamic therapy for choroidal hemangioma associated with serous retinal detachment. Arch Ophthalmol. 2002; 120: 1155-61.

50. Sheidow TG, Harbour JW. Photodynamic therapy for circumscribed choroidal hemangioma.

Can J Ophthalmol. 2002; 37: 314-7.

51. Shields JA.Photodynamic therapy for choroidal hemangioma. Graefes Arch Clin Exp Ophthalmol. 2006; 244: 1071-2

52. Singh AD, Kaiser PK, Sears JE, Gupta M, Rundle PA, Rennie IG. Photodynamic therapy of circumscribed choroidal hemangioma. Br J Ophthalmol. 2004; 88: 1414-8 
704

705

706

707

708

709

710

711

712

713

714

715

716

717

718

719

720

721

722

723

724

725

726

727

728

729

730

731

732

733

734

735

53. Tuncer S, Demirci H, Shields CL, Shields JA. Polypoidal choroidal vasculopathy following photodynamic therapy for choroidal hemangioma. Eur J Ophthalmol. 2009; 19: $159-62$.

54. Verbraak FD, Schlingemann RO, de Smet MD, Keunen JE. Single spot PDT in patients with circumscribed choroidal hemangioma and near normal visual acuity. Graefes Arch Clin Exp Ophthalmol. 2006; 244(9): 1178-82

55. Vicuna-Kojchen J, Banin E, Averbukh E, Barzel I, Shulman M, Hemo I, Pe'er J, Chowers I. Application of the standard photodynamic treatment protocol for symptomatic circumscribed choroidal hemangioma. Ophthalmologica. 2006;220(6):351-5.

56. Xiong $Y$, Zhang F.Photodynamic therapy for circumscribed choroidal hemangioma Zhonghua Yan Ke Za Zhi. 2007; 43: 1085-8

57. Zhang Y, Liu W, Fang Y, Qian J, Xu G, Wang W, Li L, Shen Y, Gao Q. Photodynamic therapy for symptomatic circumscribed macular choroidal hemangioma in Chinese patients. Am J Ophthalmol. 2010; 150: 710-715.e1.

58. Hsu CC, Yang CS, Peng CH, Lee FL, Lee SM. Combination photodynamic therapy and intravitreal bevacizumab used to treat circumscribed choroidal hemangioma. J Chin Med Assoc. 2011; 74: 473-7.

59. Blasi MA, Tiberti AC, Scupola A, Balestrazzi A, Colangelo E, Valente P, Balestrazzi E. Photodynamic therapy with verteporfin for symptomatic circumscribed choroidal hemangioma: five-year outcomes. Ophthalmology. 2010; 117: 1630-7.

60. Jurklies B, Anastassiou G, Ortmans S, Schüler A, Schilling H, Schmidt-Erfurth $U$, Bornfeld N. Photodynamic therapy using verteporfin in circumscribed choroidal hemangioma. Br J Ophthalmol. 2003; 87: 84-9

61. Porrini G, Giovannini A, Amato G, Ioni A, Pantanetti M. Photodynamic therapy of 


\section{CHOROIDAL HEMANGIOMA TREATMENT}

736

circumscribed choroidal hemangioma. Ophthalmology. 2003; 110: 674-80.

737

738

62. Lee V, Hungerford JL.Proton beam therapy for posterior pole circumscribed choroidal

739 hemangioma. Eye (Lond). 1998; 12: 925-8.

740

741

742

743 


\section{CHOROIDAL HEMANGIOMA TREATMENT}

\section{Figures}

745

746 Figure 1. Superonasally located circumscribed choroidal hemangioma placed under

747 observation at baseline $[A]$ and at 10 months follow up [B] - SD-OCT indicating the presence

748 of overlying intraretinal fluid. [C]. No change noted in dimensions of the lesion during the

749 follow up period.

A

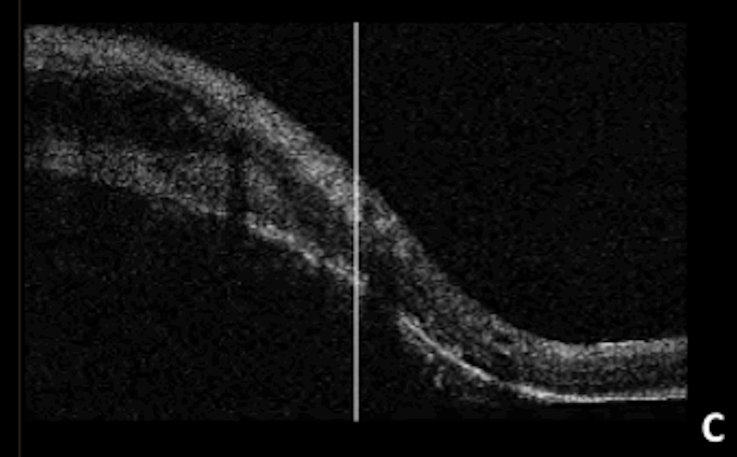

750

751

752 


\section{CHOROIDAL HEMANGIOMA TREATMENT}

753 Figure 2- Circumscribed choroidal hemangioma treated with lens-sparing external beam

754 radiotherapy. Top panel: (A) pre-treatment (B) at 15 months follow up - loss of overyling 755 orange pigment, absoprtion of overlying subretinal fluid and visual acuity improvement from

$7566 / 9$ at baseline to $6 / 6$ at end of follow up. Middle panel: (C ) pre-treatment (D) Four years 757 after treatment hemangioma was atrophic. Visual acuity improved from 6/12 to 6/6. Bottom 758 panel: (E) Circumscribed choroidal hemangioma 12 months after LS-EBRT treatment - Lesion 759 is flat and visual acuity was at $6 / 9(F, G) 20$ and 24 months after (E) radiation maculopathy 760 developed and visual acuity reduced to $6 / 36$

761

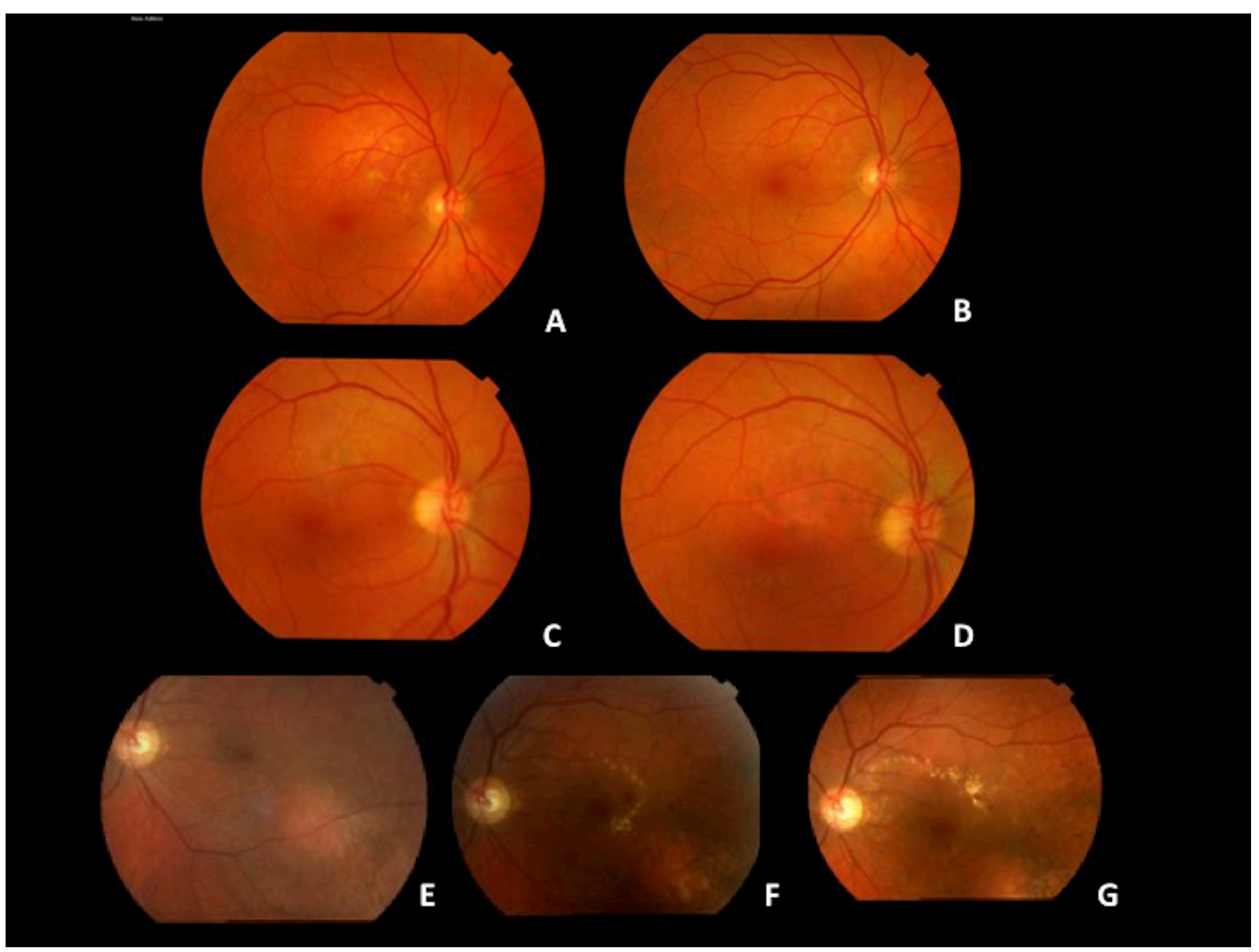


764 Figure 3. Kaplan-Meier survival analysis curves with regards to any visual acuity gain or loss $765(A, D)$, significant visual acuity gain or loss $(B, E)$ and very significant visual acuity gain or loss $766(\mathrm{C}, \mathrm{F})$ in patients with choroidal hemangioma either under observation or receiving treatment 767 with lens-sparing external beam radiotherapy (LS-EBRT) or photodynamic therapy (PDT).

768

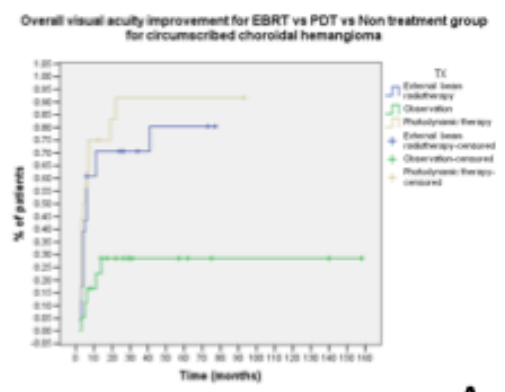

A

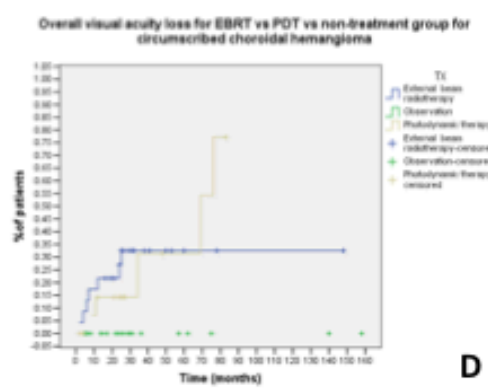

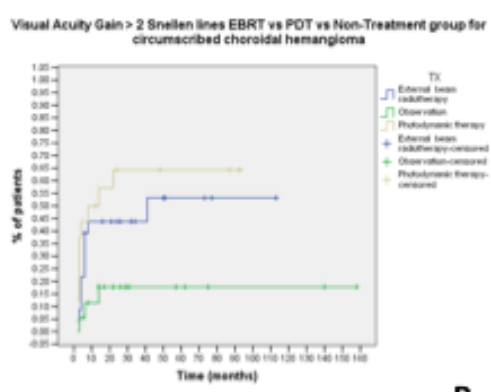

B

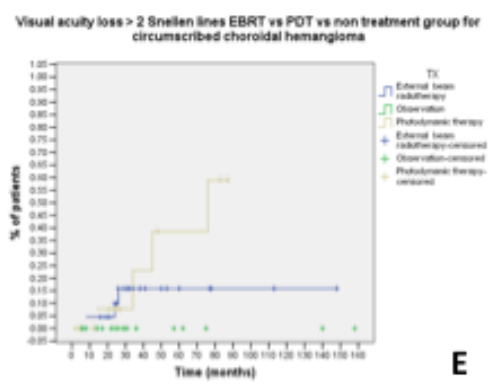

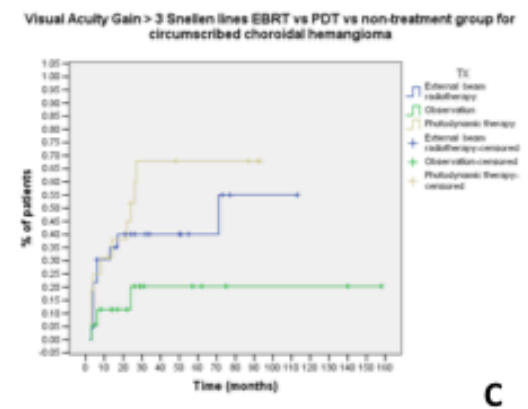

C

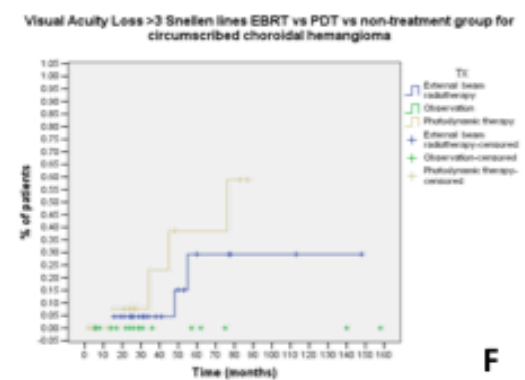

769

770 


\section{CHOROIDAL HEMANGIOMA TREATMENT}

772 Figure 4 - Juxtafoveal circumscribed choroidal hemangioma treated with standard single 773 duration PDT before (A) and 5 years after treatment (B). No change noted in the diameter of 774 the lesion. Visual acuity improved from 6/12 to 6/9. Fundus photographs and SD-OCT of 775 macular choroidal hemangioma pre treatment $(C, D, E)$ and 6 months after treatment $(F, G, H)$ 776 with double duration PDT. Lesion thickness reduced to undetectable and macular anatomy 777 was restored.

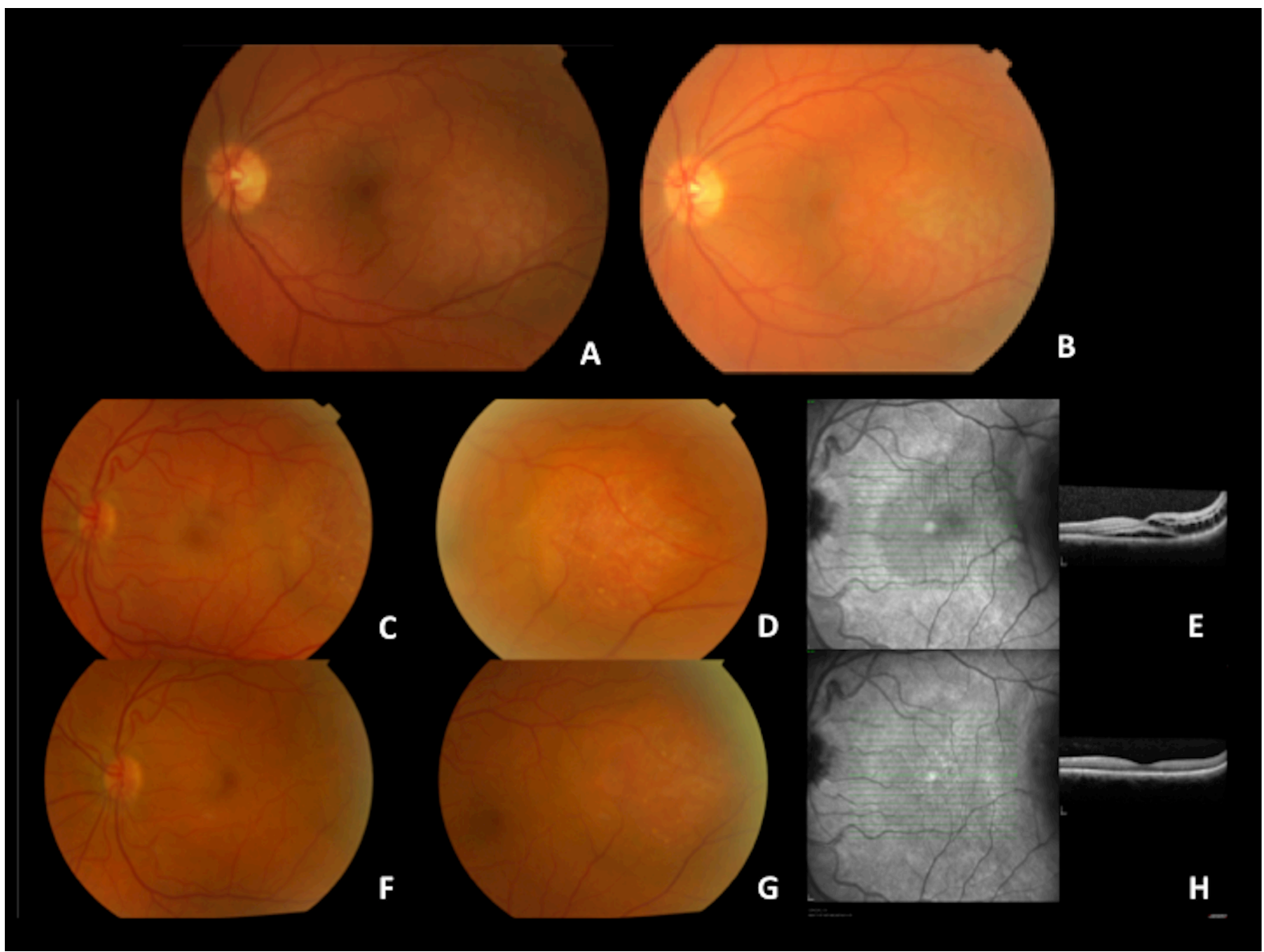




\section{CHOROIDAL HEMANGIOMA TREATMENT}

781 Figure 5. Juxtafoveal circumcribed choroidal hemangioma treated with plaque brachytherapy

782 at baseline (A), at 18 months after treatment with sparse atrophic areas in the periphery (B),

783 at 56 months after treatment with hemorrhage, exudation at the foveal area (radiation

784 maculopathy) and expansion of the atrophic areas) (C) and at 72 months with considerable

785 thinning and exudation (D). Visual acuity had reduced from 6/12 pre treatment to CF at the

786 end of follow up period.

787

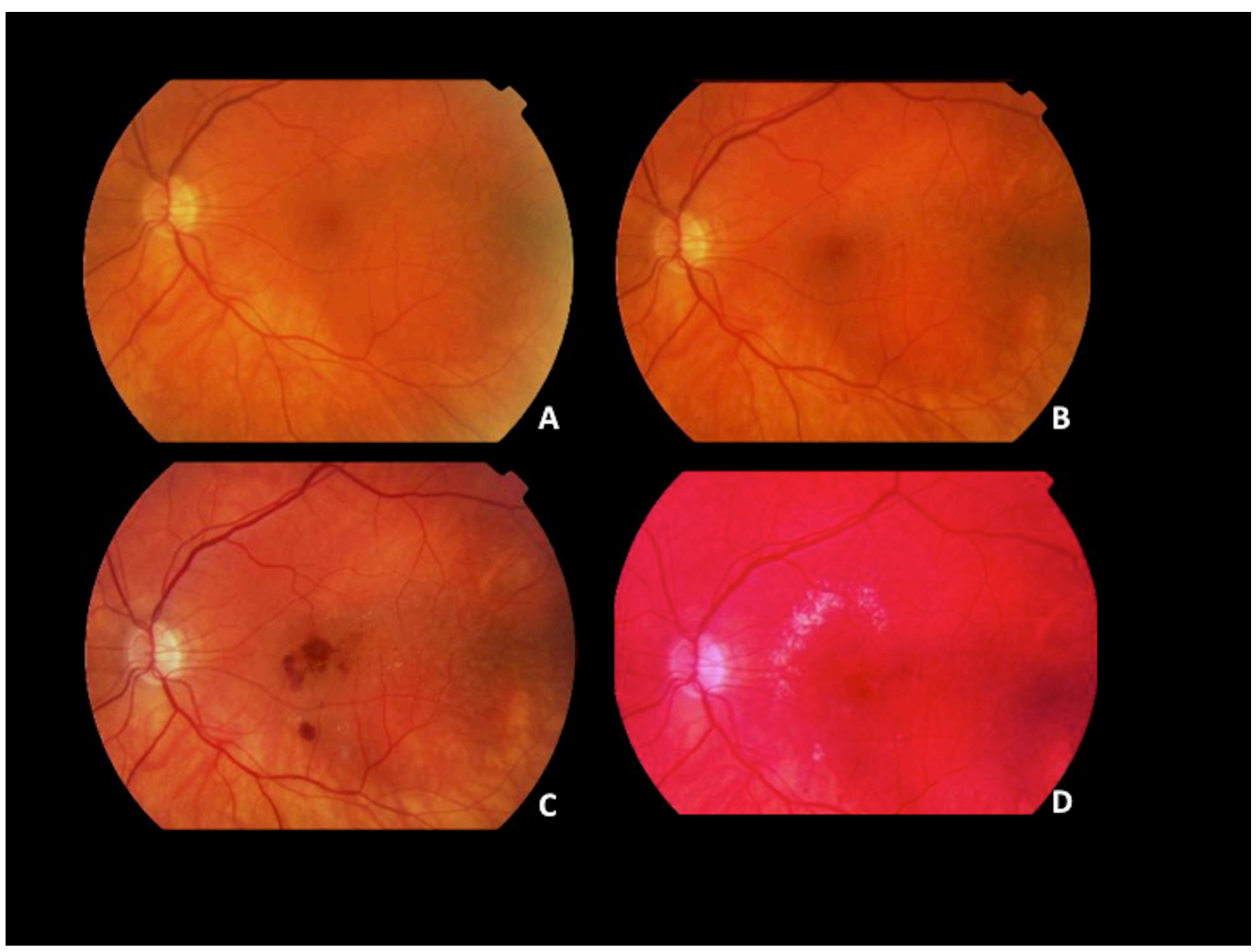

788

789

790

791 
792 Table 1. Retrospective analysis of 60 patients with circumscribed

793 choroidal hemangiomas from 2000-2014. Patient demographics and

794 features of circumscribed choroidal hemangiomas at baseline

$795{ }^{1}$ median(mean \pm SD)(range)

796 Ilocation of tumor epicentre, Quadrantic location in location to fovea (macular),

797 optic disc (juxtapapillary) and location outside the vascular arcades (peripheral)

798 3Detected clinically and on OCT

799

\begin{tabular}{|c|c|}
\hline Number of patients & 60 \\
\hline Age & $\mathbf{6 1 . 5}(58 \pm 15)(18-87)^{1}$ \\
\hline Male & $31 / 60(51 \%)$ \\
\hline Female & $29 / 60(49 \%)$ \\
\hline Follow up(months) & $\mathbf{3 1}(47 \pm 39)(2-173)^{1}$ \\
\hline \multicolumn{2}{|l|}{$\begin{array}{l}\text { Location of } \\
\text { hemangioma }^{2}\end{array}$} \\
\hline Macular & $35 / 60(58.5 \%)$ \\
\hline Superior & $6 / 35(17 \%)$ \\
\hline Inferior & $3 / 35(8.6 \%)$ \\
\hline Temporal & $25 / 35(69.7 \%)$ \\
\hline Nasal & $1 / 35(2.9 \%)$ \\
\hline Juxtapapillary & $15 / 60(25 \%)$ \\
\hline Superior & $7 / 15(46.7 \%)$ \\
\hline Inferior & $1 / 15(6.7 \%)$ \\
\hline Temporal & $3 / 15(20 \%)$ \\
\hline Nasal & $4 / 15(26.7 \%)$ \\
\hline Peripheral & $10 / 60(16.6 \%)$ \\
\hline Superior & $3 / 10(30 \%)$ \\
\hline Inferior & $3 / 10(30 \%)$ \\
\hline Temporal & $2 / 10(20 \%)$ \\
\hline Nasal & $2 / 10(20 \%)$ \\
\hline Distance to fovea & $1.5(1.92 \pm 1.6)(0-5.5)^{1}$ \\
\hline Distance to optic disc & $1.7(2.5 \pm 2.1)(0.1-8.5)^{1}$ \\
\hline
\end{tabular}


CHOROIDAL HEMANGIOMA TREATMENT

\begin{tabular}{|c|c|}
\hline Orange & $36 / 60(60 \%)$ \\
\hline Yellow & $24 / 60(40 \%)$ \\
\hline \multicolumn{2}{|l|}{$R P E$} \\
\hline Mottled pigment & $22 / 60(36.7 \%)$ \\
\hline Orange pigment & $13 / 60(21.7 \%)$ \\
\hline Fibrous metaplasia & $7 / 60(11.7 \%)$ \\
\hline Osseous metaplasia & $1 / 60(1.7 \%)$ \\
\hline No RPE changes & $17 / 60(28.3 \%)$ \\
\hline \multicolumn{2}{|l|}{ Exudation } \\
\hline Yes & $2 / 60(3.3 \%)$ \\
\hline No & $58 / 60(96.7 \%)$ \\
\hline \multicolumn{2}{|l|}{ Drusen } \\
\hline Yes & $14 / 60(23.3 \%)$ \\
\hline No & $46 / 60(76.7 \%)$ \\
\hline \multicolumn{2}{|l|}{$\begin{array}{l}\text { Intraretinal or } \\
\text { Subretinal fluid }{ }^{3}\end{array}$} \\
\hline Yes & $46 / 60(77 \%)$ \\
\hline No & $14 / 60(23 \%)$ \\
\hline \multicolumn{2}{|l|}{ Haemorrhage } \\
\hline Yes & $1 / 60(1.6 \%)$ \\
\hline No & $59 / 60(96.7 \%)$ \\
\hline
\end{tabular}

800

801 
802 Table 2

803 Retrospective analysis of 60 patients with circumscribed choroidal 804 hemangiomas from 2000-2014. Treatment vs no treatment group 805 features at baseline

$806{ }^{1} p$ value was determined by $x^{2}$ or Mann-Whitney (see text)

$807 \quad$ Median (mean $\pm S D$, range)

\begin{tabular}{|c|c|c|c|}
\hline & Treatment group & $\begin{array}{l}\text { Non-treatment } \\
\text { group }\end{array}$ & $\underline{\text { Pvalue }^{1}}$ \\
\hline $\begin{array}{l}\text { Number of } \\
\text { patients }\end{array}$ & $42 / 60(70 \%)$ & $18 / 60(30 \%)$ & \\
\hline Male & $21 / 60(67.7 \%)$ & $10 / 60(32.3 \%)$ & \\
\hline Female & $21 / 60(72.4 \%)$ & $8 / 60(27.6 \%)$ & \\
\hline \multicolumn{4}{|l|}{ Location } \\
\hline $\begin{array}{l}\text { Juxtapapillar } \\
y\end{array}$ & $10 / 15(66 \%)$ & $5 / 15(34 \%)$ & 0.197 \\
\hline Macular & $27 / 35(77 \%)$ & $8 / 35(23 \%)$ & 0.001 \\
\hline Peripheral & $5 / 10(50 \%)$ & $5 / 10(50 \%)$ & 1 \\
\hline $\begin{array}{l}\text { Height } \\
\text { baseline }\end{array}$ & $2.7(2.9 \pm 1,1.5-6.6)^{2}$ & $2(2.2 \pm 1,1-4.7)$ & $0.018(\mathrm{mw})$ \\
\hline $\begin{array}{l}\text { Diameter at } \\
\text { baseline }\end{array}$ & $\begin{array}{l}7.6(7.2 \pm 2.8, \quad 2.5- \\
16.3)\end{array}$ & $\begin{array}{l}6.9(6.7 \pm 2.3, \quad 3.5- \\
11.2)\end{array}$ & 0.61 \\
\hline Color & & & 0.571 \\
\hline Orange & $25 / 36(69.5 \%)$ & $11 / 36(30.5 \%)$ & \\
\hline Yellow & $17 / 24(70 \%)$ & $7 / 24(30 \%)$ & \\
\hline \multicolumn{4}{|l|}{ RPE changes } \\
\hline $\begin{array}{l}\text { Mottled } \\
\text { pigment }\end{array}$ & $16 / 22(73 \%)$ & $6 / 22(27 \%)$ & 0.03 \\
\hline $\begin{array}{l}\text { Orange } \\
\text { pigment }\end{array}$ & $12 / 13(92.3 \%)$ & $1 / 13(7.7 \%)$ & 0.008 \\
\hline $\begin{array}{l}\text { Fibrous } \\
\text { metaplasia }\end{array}$ & $3 / 7(42.9 \%)$ & $4 / 7(57.1 \%)$ & 0.7 \\
\hline $\begin{array}{l}\text { Osseous } \\
\text { metaplasia }\end{array}$ & $1 / 1(100 \%)$ & $0 / 1(0 \%)$ & \\
\hline
\end{tabular}


CHOROIDAL HEMANGIOMA TREATMENT

809

\begin{tabular}{|l|l|l|l|}
\hline $\begin{array}{l}\text { No RPE } \\
\text { changes }\end{array}$ & $10 / 17(58.8 \%)$ & $7 / 17(41.2 \%)$ & 0.467 \\
\hline $\begin{array}{l}\text { Exudation } \\
\text { present }\end{array}$ & $0 / 2(0 \%)$ & $2 / 2(100 \%)$ & \\
\hline $\begin{array}{l}\text { Drusen } \\
\text { present }\end{array}$ & $9 / 14(64.3 \%)$ & $5 / 14(35.7 \%)$ & 0.285 \\
\hline $\begin{array}{l}\text { Drusen } \\
\text { absent }\end{array}$ & $33 / 46(71.7 \%)$ & $13 / 46(28.3 \%)$ & 0.003 \\
\hline $\begin{array}{l}\text { Hemorrhage } \\
\text { present }\end{array}$ & $1 / 1(100 \%)$ & $0 / 1(0 \%)$ & \\
\hline
\end{tabular}

810 
Table 3

Retrospective analysis of 60 patients with circumscribed choroidal hemangiomas from 2000-2014 Visual acuity outcomes at the end of follow up period.

\begin{tabular}{|c|c|c|c|c|c|c|c|c|c|c|}
\hline$\frac{\text { Treatment }}{\underline{\text { Groups }}}$ & $\frac{\text { VA }}{\text { preTx }}$ & $\frac{\text { VApostT }}{\underline{x}}$ & VAdiff & $\begin{array}{l}\text { GAIN }>3 \\
\text { SNELLEN } \\
\underline{\text { LINES }}\end{array}$ & $\begin{array}{l}\frac{\text { GAIN }>2}{\text { SNELLEN }} \\
\underline{\text { LINES }}\end{array}$ & $\frac{\text { ANY }}{\text { GAIN }}$ & $\underline{\text { ANY }}$ & $\begin{array}{l}\frac{\text { LOSS }>2}{\text { SNELLEN }} \\
\underline{\text { LINES }}\end{array}$ & $\begin{array}{l}\text { LOSS }>3 \\
\underline{\text { SNELLEN }} \\
\underline{\text { LINES }}\end{array}$ & $\frac{\text { NO }}{\text { CHANGE }}$ \\
\hline Observation & $\begin{array}{l}0.66 \pm 0 . \\
45\end{array}$ & $\begin{array}{l}0.74 \pm 0.4 \\
5\end{array}$ & $\begin{array}{l}0.08 \pm 0.2 \\
3\end{array}$ & $\begin{array}{l}2 / 18 \\
(11.1 \%)\end{array}$ & $\begin{array}{l}3 / 18 \\
(16.7 \%)\end{array}$ & $\begin{array}{l}6 / 18 \\
(33 \%)\end{array}$ & $\begin{array}{l}1 / 18 \\
(5.6 \%)\end{array}$ & $\begin{array}{l}1 / 18 \\
(5.6 \%)\end{array}$ & $\begin{array}{l}1 / 18 \\
(5.6 \%)\end{array}$ & $\begin{array}{l}11 / 18 \\
(61 \%)\end{array}$ \\
\hline$\underline{\text { LS-EBRT }}$ & $\begin{array}{l}0.45 \pm 0 . \\
23\end{array}$ & $0.68 \pm 0.4$ & $\begin{array}{l}0.22 \pm 0.3 \\
4\end{array}$ & $\begin{array}{l}11 / 23 \\
(47.8 \%)\end{array}$ & $\begin{array}{l}12 / 23 \\
(52.2 \%)\end{array}$ & $\begin{array}{c}14 / 23 \\
(61 \%)\end{array}$ & $\begin{array}{l}6 / 23 \\
(26 \%)\end{array}$ & $\begin{array}{l}4 / 23 \\
(17.4 \%)\end{array}$ & $\begin{array}{l}2 / 23 \\
(8.7 \%)\end{array}$ & $\begin{array}{l}3 / 23 \\
(13 \%)\end{array}$ \\
\hline$\underline{\text { PDT }}$ & $\begin{array}{l}0.46 \pm 0 \\
17\end{array}$ & $0.67 \pm 0.4$ & $0.3 \pm 0.51$ & $\begin{array}{l}4 / 16 \\
(25 \%)\end{array}$ & $\begin{array}{l}8 / 16 \\
(50 \%)\end{array}$ & $\begin{array}{l}13 / 16 \\
(81 \%)\end{array}$ & $\begin{array}{l}3 / 16 \\
(6.3 \%)\end{array}$ & $\begin{array}{l}2 / 16 \\
(18.75 \%)\end{array}$ & $\begin{array}{l}2 / 16 \\
(12.5 \%)\end{array}$ & $\begin{array}{l}0 / 16 \\
(0 \%)\end{array}$ \\
\hline PLAQUE & $\begin{array}{l}0.35 \pm 0 . \\
13\end{array}$ & $0.1 \pm 0.17$ & $-0.2 \pm 0.3$ & $\begin{array}{l}0 / 3 \\
(0 \%)\end{array}$ & $\begin{array}{l}0 / 3 \\
(0 \%)\end{array}$ & $\begin{array}{c}0 / 3 \\
(0 \%)\end{array}$ & $\begin{array}{l}3 / 3 \\
(100 \%)\end{array}$ & $\begin{array}{l}3 / 3 \\
(100 \%)\end{array}$ & $\begin{array}{l}2 / 3 \\
(66.7 \%)\end{array}$ & $\begin{array}{l}0 / 3 \\
(0 \%)\end{array}$ \\
\hline
\end{tabular}


817 Table 4

818 Retrospective analysis of 60 patients with circumscribed choroidal 819 hemangiomas from 2000-2014 . Log rank test results for observation, 820 LS-EBRT and PDT groups following Kaplan-Meier analysis.

821

\begin{tabular}{|c|c|c|c|}
\hline Visual acuity & Groups & Observation & LS-EBRT \\
\hline \multirow[t]{3}{*}{ Any gain } & Observation & & \\
\hline & LS-EBRT & 0.003 & \\
\hline & PDT & $<0.001$ & 0.24 \\
\hline \multirow[t]{3}{*}{ Gain >2 Snellen lines } & Observation & & \\
\hline & LS-EBRT & 0.049 & \\
\hline & PDT & 0.006 & 0.29 \\
\hline \multirow[t]{3}{*}{ Gain $>3$ Snellen lines } & Observation & & \\
\hline & LS-EBRT & 0.098 & \\
\hline & PDT & 0.014 & 0.339 \\
\hline \multirow[t]{3}{*}{ Any loss } & Observation & & \\
\hline & LS-EBRT & 0.02 & \\
\hline & PDT & 0.02 & 0.948 \\
\hline \multirow[t]{3}{*}{ Loss $>2$ Snellen lines } & Observation & & \\
\hline & LS-EBRT & 0.157 & \\
\hline & PDT & 0.052 & 0.32 \\
\hline \multirow[t]{3}{*}{ Loss $>3$ Snellen lines } & Observation & & \\
\hline & LS-EBRT & 0.151 & \\
\hline & PDT & 0.052 & 0.23 \\
\hline
\end{tabular}


Table 5

Retrospective analysis of 14 patients with circumscribed choroidal hemangiomas treated with photodynamic therapy (PDT) (standard settings vs double duration). Visual acuity results, Hemangioma Thickness / Maximal Diameter difference and OCT CRT difference

\begin{tabular}{|c|c|c|c|c|c|c|c|c|c|c|}
\hline Parameter & $\underline{\text { PDT settings }}$ & $\underline{\mathbf{F U}}$ & $\underline{\mathbf{N}}$ & $\frac{\text { Median (mean }}{\text { range) }}=S D$, & $\begin{array}{l}\frac{\text { GAIN }}{23} \\
\underline{\underline{\text { LINES }}}\end{array}$ & $\begin{array}{l}\frac{\text { GAIN }}{\geq 2} \\
\underline{\underline{\text { LINES }}}\end{array}$ & $\underline{\underline{\text { ANY }}}$ & $\underline{\underline{\text { ANY }}}$ & $\frac{\text { LOSS }>2}{\underline{\text { LINES }}}$ & $\begin{array}{l}\text { LOSS >3 } \\
\underline{\text { LINES }}\end{array}$ \\
\hline $\begin{array}{l}\text { Visual acuity } \\
\text { change }\end{array}$ & Standard settings & $58 \pm 40$ & 5 & $\begin{array}{l}-0.05(0.06 \pm 0.46,- \\
0.05-0.7)\end{array}$ & $\begin{array}{l}1 / 5 \\
(25 \%)\end{array}$ & $\begin{array}{l}2 / 5 \\
(40 \%)\end{array}$ & $\begin{array}{l}2 / 5 \\
(40 \%)\end{array}$ & $\begin{array}{l}3 / 5 \\
(60 \%)\end{array}$ & $\begin{array}{l}2 / 5 \\
(40 \%) \\
\end{array}$ & $\begin{array}{l}2 / 5 \\
(40 \%)\end{array}$ \\
\hline$(p=1.9)$ & Double duration & $19 \pm 10$ & 9 & $\begin{array}{l}0.33(0.47 \pm 0.53,-0.1- \\
1.7)\end{array}$ & $\begin{array}{l}3 / 9 \\
(33 \%)\end{array}$ & $\begin{array}{l}6 / 9 \\
(66 \%)\end{array}$ & $\begin{array}{l}9 / 9 \\
(100 \%)\end{array}$ & $\begin{array}{l}0 / 9 \\
(0 \%)\end{array}$ & $\begin{array}{l}0 / 9 \\
(0 \%)\end{array}$ & $\begin{array}{l}0 / 9 \\
(0 \%)\end{array}$ \\
\hline $\begin{array}{l}\text { Height change } \\
(\mathrm{mm})\end{array}$ & Standard settings & & 5 & $\begin{array}{l}-0.1(-0.36 \pm 0.57,-1.2- \\
0.2)\end{array}$ & & & & & & \\
\hline$(p=0.042)$ & Double duration & & 9 & $\begin{array}{l}-1(-1.3 \pm 0.77,-2.5-- \\
0.3)\end{array}$ & & & & & & \\
\hline $\begin{array}{l}\text { Max diam } \\
\text { change (mm) }\end{array}$ & Standard settings & & 5 & $\begin{array}{l}1.5(0.58 \pm 2.8,-3.8- \\
3.7)\end{array}$ & & & & & & \\
\hline$(p=0.147)$ & Double duration & & 9 & $-0.2(-1.4 \pm 2,-5.2-0.2)$ & & & & & & \\
\hline $\begin{array}{l}\text { OCT CRT change } \\
(\mu \mathrm{m})\end{array}$ & Standard settings & & 3 & $82(138 \pm 181,-8-341)$ & & & & & & \\
\hline$(p=0.018)$ & Double duration & & 9 & $\begin{array}{l}-202(-184 \pm 131,-391- \\
0)\end{array}$ & & & & & & \\
\hline
\end{tabular}


830

831

832

833

834

Table 6.

Retrospective analysis of 60 patients with circumscribed choroidal hemangiomas from 2000-2014 Radiationrelated complications

\begin{tabular}{|c|c|c|c|}
\hline Treatment modality & $\frac{\text { Time point after treatment }}{\text { (mo.) }}$ & Complication & Treatment required \\
\hline LS-EBRT & 76 & Hemorrhage & $\mathbf{N}$ \\
\hline LS-EBRT & 47 & Hemorrhage, exudate & $\mathbf{N}$ \\
\hline LS-EBRT & 33 & Hemorrhage, exudate & $\mathbf{N}$ \\
\hline LS-EBRT & 68 & Hemorrhage, exudate & $\mathbf{N}$ \\
\hline LS-EBRT & 9 & Macular edema & Avastin \\
\hline LS-EBRT & 25 & Cotton wool spots & $\mathbf{N}$ \\
\hline LS-EBRT & 25 & Cotton wool spots & $\mathbf{N}$ \\
\hline
\end{tabular}


CHOROIDAL HEMANGIOMA TREATMENT

\section{6}

837

838 839

\begin{tabular}{|c|c|c|c|c|c|c|c|c|c|c|}
\hline Publication & Type & $\underline{\mathbf{N}}$ & CCH location & $\begin{array}{l}\text { Follow } \\
\text { up (mo) }\end{array}$ & PDT settings & Prior Tx & Post Tx & $\begin{array}{l}\text { Sessions of } \\
\text { PDT }\end{array}$ & $\begin{array}{l}\text { Visual acuity } \\
\text { outcomes (1) }\end{array}$ & $\begin{array}{l}\text { CCH thickness } \\
\text { outcomes (mm) }\end{array}$ \\
\hline Chan, 2014 & $\begin{array}{l}\text { Case } \\
\text { report }\end{array}$ & 1 & Juxtapapillary & $\overrightarrow{14}$ & $\begin{array}{l}\text { Standard PDT } \\
63 \mathrm{sec} \\
\end{array}$ & antiVEGF & & 1 & +0.4 & -2.0 \\
\hline Bazin, 2012 & $\begin{array}{l}\text { Case } \\
\text { report }\end{array}$ & 1 & $\mathrm{~N} / \mathrm{A}$ & 9 & Standard PDT & $\begin{array}{l}\text { Dexamethas } \\
\text { one } \\
\text { intravitreal } \\
\text { implant } \\
\end{array}$ & & 1 & +0.2 & 0.0 \\
\hline Bhatt, 2011 & $\begin{array}{l}\text { Case } \\
\text { report }\end{array}$ & 1 & $\mathrm{~N} / \mathrm{A}$ & 6 & Standard PDT & & & 1 & +0.2 & $\mathrm{~N} / \mathrm{A}$ \\
\hline $\begin{array}{l}\text { Elizalde, } \\
2012\end{array}$ & $\begin{array}{l}\text { Case } \\
\text { series }\end{array}$ & 13 & $\begin{array}{l}\text { Subfoveal }(\mathrm{n}=4) \\
\text { Juxtafoveal }(\mathrm{n}=3) \\
\text { Extrafoveal } \\
(\mathrm{n}=2) \\
\text { Juxtapapillary } \\
(\mathrm{n}=4)\end{array}$ & $7-67$ & Standard PDT & & EBRT $(n=1)$ & $\begin{array}{l}54 \%(n=7) 1 \\
38 \%(n=5) 2 \\
7.7 \%(n=1) 5\end{array}$ & $\begin{array}{l}+0.1-+0.5 \\
(\mathrm{n}=11) \\
0.0(\mathrm{n}=2)\end{array}$ & 3.4 to $2.5 \mathrm{~mm}^{(2)}$ \\
\hline Hsu, 2011 & $\begin{array}{l}\text { Case } \\
\text { report }\end{array}$ & 1 & Juxtafoveal & 12 & $\begin{array}{l}\text { Standard PDT } \\
113 \mathrm{sec}\end{array}$ & & antiVEGF & 1 & +0.05 & -1.4 \\
\hline $\begin{array}{l}\text { Pilotto, } \\
2011\end{array}$ & $\begin{array}{l}\text { Case } \\
\text { series }\end{array}$ & 20 & $\begin{array}{l}\text { Subfoveal }(\mathrm{n}=2) \\
\text { Extrafoveal } \\
(\mathrm{n}=13) \\
\text { Juxtapapillary } \\
(\mathrm{n}=5)\end{array}$ & 58 & $\begin{array}{l}\text { Standard PDT } \\
(\mathrm{n}=10) \\
\text { Bolus infusion } \\
166 \mathrm{sec} \\
\text { duration } \\
(\mathrm{n}=10)\end{array}$ & TTT $(n=2)$ & & 1 & $\begin{array}{l}0.0 \quad(n=10) \\
+0.1(n=4) \\
+0.2(n=5) \\
-0.3(n=1)\end{array}$ & -2.4 \\
\hline $\begin{array}{l}\text { Andonegui, } \\
2010\end{array}$ & $\begin{array}{l}\text { Case } \\
\text { series }\end{array}$ & 2 & $\begin{array}{l}\text { Extrafoveal } \\
\text { (n=1) } \\
\text { Juxtapapillary } \\
(\mathrm{n}=1)\end{array}$ & 9 and 15 & Standard PDT & & & 1 & +0.1 and +0.3 & 0.0 and -1.5 \\
\hline Liu, 2011 & $\begin{array}{l}\text { Case } \\
\text { series }\end{array}$ & 14 & $\begin{array}{l}\text { Subfoveal }(\mathrm{n}=10) \\
\text { Extrafoveal } \\
(\mathrm{n}=1) \\
\text { Juxtapapillary } \\
(\mathrm{n}=3)\end{array}$ & $12-42$ & $\begin{array}{l}\text { Standard PDT } \\
\text { (one case at } \\
125 \text { seconds) }\end{array}$ & & & 1 & +0.1 & $-1.8(4)$ \\
\hline
\end{tabular}

Table 7.: Representative case series and case reports of patients with circumscribed choroidal hemangioma treated with photodynamic therapy 
CHOROIDAL HEMANGIOMA TREATMENT

\begin{tabular}{|c|c|c|c|c|c|c|c|c|c|c|}
\hline Zhang, 2010 & $\begin{array}{l}\text { Case } \\
\text { series }\end{array}$ & 25 & $\begin{array}{l}\text { Subfoveal }(\mathrm{n}=18) \\
\text { Perifoveal }(\mathrm{n}=7)\end{array}$ & $35 \pm 15$ & $\begin{array}{l}\text { Standard PDT } \\
\text { for subfoveal } \\
75 \mathrm{~J} / \mathrm{cm} 2 \text { and } 12 \\
\text { for perifoveal }\end{array}$ & $5 \mathrm{sec}$ & & $\begin{array}{l}1 \\
2(n=2)\end{array}$ & $+0.21^{(4)}$ & 3.2 to $-1.3^{(4)}$ \\
\hline Blasi, 2010 & $\begin{array}{l}\text { Case } \\
\text { series }\end{array}$ & 25 & $\begin{array}{l}\text { Subfoveal }(\mathrm{n}=2) \\
\text { Juxtrafoveal } \\
(\mathrm{n}=9) \\
\text { Extrafoveal } \\
(\mathrm{n}=14)\end{array}$ & $60+$ & $\begin{array}{l}\text { Standard PDT } \\
\text { for three cases } \\
\text { and double } \\
\text { power } 100 \\
\mathrm{~J} / \mathrm{cm} 2 \text { and } \\
\text { duration for the } \\
\text { remainder }\end{array}$ & & & $1(n=22)$ & +0.04 to +0.15 & $-2.31^{(4)}$ \\
\hline $\begin{array}{l}\text { Chalam, } \\
2009\end{array}$ & $\begin{array}{l}\text { Case } \\
\text { report }\end{array}$ & 1 & Juxtafoveal & 1 & Standard PDT & & & 1 & 0.23 & $\mathrm{~N} / \mathrm{A}$ \\
\hline $\begin{array}{l}\text { Wachtlin, } \\
2009\end{array}$ & $\begin{array}{l}\text { Case } \\
\text { series }\end{array}$ & 13 & $\begin{array}{l}\text { Subfoveal }(\mathrm{n}=7) \\
\text { Juxtapapillary } \\
(\mathrm{n}=6)\end{array}$ & 26 & $\begin{array}{l}\text { 75J PDT 125 } \\
\text { sec / paint } \\
\text { brush } \\
\text { application }\end{array}$ & & & 1 & 0.25 & -1.7 to -1.8 \\
\hline $\begin{array}{l}\text { Sagong, } \\
2009\end{array}$ & $\begin{array}{l}\text { Case } \\
\text { series }\end{array}$ & 2 & $\begin{array}{l}\text { Extrafoveal } \\
(\mathrm{n}=1) \\
\text { Juxtapapillary } \\
(\mathrm{n}=1)\end{array}$ & 6 and 9 & Standard PDT & $\begin{array}{l}\text { antiVEGF } \\
(\mathrm{n}=1)\end{array}$ & $\begin{array}{l}\text { antiVEGF } \\
(n=2)\end{array}$ & 1 & +0.2 to +0.4 & $-2.3^{(4)}$ \\
\hline $\begin{array}{l}\text { Huang, } \\
2009\end{array}$ & $\begin{array}{l}\text { Case } \\
\text { series }\end{array}$ & 14 & Subfoveal $(\mathrm{n}=7)$ & 6-36 & Standard PDT & & IVTA $(\mathrm{n}=4)$ & $\begin{array}{l}1(\mathrm{n}=8) \\
2(\mathrm{n}=6)\end{array}$ & +0.1 & $-2.2^{(4)}$ \\
\hline $\begin{array}{l}\text { Tuncer, } \\
2009\end{array}$ & $\begin{array}{l}\text { Case } \\
\text { report }\end{array}$ & 1 & juxtapapillary & 36 & Standard PDT & & & 1 & 0 & -2.7 \\
\hline $\begin{array}{l}\text { Boixadera } \\
\text { et al } \\
\text { Ophthalmo } \\
\text { logy } 2008\end{array}$ & $\begin{array}{l}\text { Case } \\
\text { series }\end{array}$ & 31 & $\begin{array}{l}\text { Subfoveal }(\mathrm{n}=3) \\
\text { Juxtafoveal }(\mathrm{n}=7) \\
\text { Extrafoveal } \\
(\mathrm{n}=10) \\
\text { Juxtapapillary } \\
(\mathrm{n}=9)\end{array}$ & 12 & Standard PDT & $\begin{array}{l}\text { TTT } \\
(\mathrm{n}=2) \\
\text { laser } \\
(\mathrm{n}=2) \\
\text { TTT and } \\
\text { laser }(\mathrm{n}=2)\end{array}$ & & $1-3$ & +0.2 & -2.3 \\
\hline $\begin{array}{l}\text { Lopez- } \\
\text { Quero et al }\end{array}$ & $\begin{array}{l}\text { Case } \\
\text { report }\end{array}$ & 1 & Subfoveal & 17 & Standard PDT & & & 4 & 0 & -3.4 \\
\hline
\end{tabular}


CHOROIDAL HEMANGIOMA TREATMENT

\begin{tabular}{|c|c|c|c|c|c|c|c|c|c|c|}
\hline $\begin{array}{l}\text { Arch Soc } \\
\text { Esp Sep } \\
2008\end{array}$ & & & & & & & & & & \\
\hline $\begin{array}{l}\text { Vicuna - } \\
\text { Kojchen et } \\
\text { al } \\
\text { Ophthalmo } \\
\text { logica } 2006\end{array}$ & $\begin{array}{l}\text { Case } \\
\text { series }\end{array}$ & 9 & $\begin{array}{l}\text { Subfoveal }(n=2) \\
\text { Juxtafoveal }(n=1) \\
\text { Extrafoveal } \\
(n=2) \\
\text { Juxtapapillary } \\
(n=1) \\
\text { Peripheral }(n=3)\end{array}$ & $2-24$ & Standard PDT & & & $1-3$ & +0.15 & -1.7 \\
\hline $\begin{array}{l}\text { Kubicka- } \\
\text { Trzaska et } \\
\text { al Klin } \\
\text { Oczna } 2006\end{array}$ & $\begin{array}{l}\text { Case } \\
\text { series }\end{array}$ & 4 & $\begin{array}{l}\text { Subfoveal }(n=2) \\
\text { Extrafoveal } \\
(n=2)\end{array}$ & $3-14$ & Standard PDT & & & $\begin{array}{l}1(n=3) \\
4(n=1)\end{array}$ & $\mathrm{N} / \mathrm{A}$ & $\mathrm{N} / \mathrm{A}$ \\
\hline $\begin{array}{l}\text { Leys A et al } \\
\text { Retina Jul } \\
\text { Aug } 2006\end{array}$ & $\begin{array}{l}\text { Case } \\
\text { series }\end{array}$ & 3 & $\begin{array}{l}\text { Subfoveal }(n=1) \\
\text { Juxtafoveal }(n=2)\end{array}$ & 12 & $\begin{array}{l}\text { Standard PDT } \\
(\mathrm{n}=2) \\
\text { 100J PDT } \\
\text { 166sec }(\mathrm{n}=1)\end{array}$ & & IVTA & $1,2,4$ & +0.1 & -2.7 \\
\hline $\begin{array}{l}\text { Verbraak et } \\
\text { al Graefes } \\
\text { Sep } 2003\end{array}$ & $\begin{array}{l}\text { Case } \\
\text { series }\end{array}$ & 13 & $\begin{array}{l}\text { Subfoveal }(n=4) \\
\text { Juxtafoveal }(n=1) \\
\text { Extrafoveal } \\
(n=3) \\
\text { Juxtapapillary } \\
(n=5)\end{array}$ & $3-22$ & $\begin{array}{l}\text { Standard PDT } \\
(\mathrm{n}=10) \\
100 J \text { PDT } \\
166 \sec (\mathrm{n}=3)\end{array}$ & $\begin{array}{l}\text { Laser and } \\
\text { EBRT }(\mathrm{n}=1) \\
\text { EBRT }(\mathrm{N}=1)\end{array}$ & & $1-2$ & +0.2 & -3.0 \\
\hline $\begin{array}{l}\text { Hussain N } \\
\text { et al Ophth } \\
\text { Surg Lasers } \\
\text { Imaging Jan } \\
2006\end{array}$ & $\begin{array}{l}\text { Case } \\
\text { report }\end{array}$ & 1 & Extrafoveal & 16 & Standard PDT & & & 2 & 0 & -1.3 \\
\hline $\begin{array}{l}\text { Michels et } \\
\text { al Retina } \\
\text { Sep } 2005\end{array}$ & $\begin{array}{l}\text { Case } \\
\text { series }\end{array}$ & 15 & $\begin{array}{l}\text { Subfoveal }(n=3) \\
\text { Extrafoveal } \\
(n=12)\end{array}$ & 36.6 & $\begin{array}{l}\text { Bolus infusion, } \\
\text { double fluence, } \\
166 \text { sec. }\end{array}$ & & & 2.3 & +0.2 & -3.8 \\
\hline
\end{tabular}


CHOROIDAL HEMANGIOMA TREATMENT

\begin{tabular}{|c|c|c|c|c|c|c|c|c|c|}
\hline $\begin{array}{l}\text { Shields CL } \\
\text { et al Ophth } \\
\text { Surg Lasers } \\
\text { Imaging } \\
\text { May-Jun } \\
2005\end{array}$ & $\begin{array}{l}\text { Case } \\
\text { report }\end{array}$ & 1 & Juxtapapillary & 1 & Standard PDT & & 1 & +0.7 & -1.8 \\
\hline $\begin{array}{l}\text { Bosch et al } \\
\text { Klin Monbl } \\
\text { Augenheik } \\
\text { d Mar } 2005\end{array}$ & $\begin{array}{l}\text { Case } \\
\text { report }\end{array}$ & 1 & Subfoveal & 2 & Standard PDT & & 2 & +0.15 & -3.3 \\
\hline $\begin{array}{l}\text { Singh AD et } \\
\text { al BJO Nov } \\
2004\end{array}$ & $\begin{array}{l}\text { Case } \\
\text { series }\end{array}$ & 10 & $\begin{array}{l}\text { Subfoveal }(\mathrm{n}=7) \\
\text { Extrafoveal } \\
(\mathrm{n}=1) \\
\text { Juxtapapillary } \\
(\mathrm{n}=2)\end{array}$ & $1-13$ & Standard PDT & $\begin{array}{l}\text { TTT }(\mathrm{n}=2) \\
\text { EBRT }\end{array}$ & $1-2$ & +0.01 & -2.6 \\
\hline $\begin{array}{l}\text { Scott IU et } \\
\text { al Ophth } \\
\text { Surg Lasers } \\
\text { Imaging } \\
\text { Jul-Aug } \\
2004\end{array}$ & $\begin{array}{l}\text { Case } \\
\text { series }\end{array}$ & 5 & $\begin{array}{l}\text { Subfoveal }(n=3) \\
\text { Juxtafoveal }(n=1) \\
\text { Juxtapapillary } \\
(n=1)\end{array}$ & 3-12 & Standard PDT & & $1-2$ & +0.2 & -1.1 \\
\hline $\begin{array}{l}\text { Soucek et } \\
\text { al Neuro } \\
\text { Endocrinol } \\
\text { Feb-Apr } \\
2004\end{array}$ & $\begin{array}{l}\text { Case } \\
\text { series }\end{array}$ & 9 & $\mathrm{~N} / \mathrm{A}$ & 8 & Standard PDT & & 1 & +0.45 & -2.3 \\
\hline $\begin{array}{l}\text { Gupta M et } \\
\text { al Eye Feb } \\
2004\end{array}$ & $\begin{array}{l}\text { Case } \\
\text { series }\end{array}$ & 2 & $\mathrm{~N} / \mathrm{A}$ & $0.5-2$ & Standard PDT & & $1-2$ & +0.3 & -2.4 \\
\hline
\end{tabular}


CHOROIDAL HEMANGIOMA TREATMENT

\begin{tabular}{|c|c|c|c|c|c|c|c|c|c|}
\hline $\begin{array}{l}\text { Nicolo et al } \\
\text { EJO Aug- } \\
\text { Sep } 2003\end{array}$ & $\begin{array}{l}\text { Case } \\
\text { report }\end{array}$ & 1 & Subfoveal & 12 & Standard PDT & & 1 & +0.65 & -1.0 \\
\hline $\begin{array}{l}\text { Porrini et al } \\
\text { Ophthalmo } \\
\text { logy Apr } \\
2003\end{array}$ & $\begin{array}{l}\text { Case } \\
\text { series }\end{array}$ & 10 & $\begin{array}{l}\text { Subfoveal }(n=4) \\
\text { Extrafoveal } \\
(n=3) \\
\text { Juxtapapillary } \\
(n=2)\end{array}$ & $7-16$ & $\begin{array}{l}\text { 100J 186sec } \\
\text { (larger than } \\
2 \mathrm{~mm}) \\
75 \mathrm{~J} 125 \mathrm{sec} \\
(\mathrm{n}=1)(\mathrm{smaller} \\
\text { than } 2 \mathrm{~mm})\end{array}$ & & $1-3$ & +0.25 & -1.3 \\
\hline $\begin{array}{l}\text { Jurklies BJO } \\
\text { Jan } 2003\end{array}$ & $\begin{array}{l}\text { Case } \\
\text { series }\end{array}$ & 19 & $\begin{array}{l}\text { Subfoveal }(n=9) \\
\text { Juxtafoveal }(n=2) \\
\text { Peripheral }(n=7)\end{array}$ & 10.6 & 100J 166sec & $\begin{array}{l}\text { EBRT } \\
(n=1) \\
\text { Laser }(n=1) \\
\text { EBRT+laser } \\
(n=1)\end{array}$ & $1-5$ & +0.2 & -1.4 \\
\hline $\begin{array}{l}\text { Landau IM } \\
\text { et al Acta } \\
\text { Ophthalmo } \\
\text { I Scand Oct } \\
2002\end{array}$ & $\begin{array}{l}\text { Case } \\
\text { series }\end{array}$ & 8 & $\begin{array}{l}\text { Juxtafoveal }(n=2) \\
\text { Juxtapapillary } \\
(n=6)\end{array}$ & $3-15$ & Standard PDT & $\begin{array}{l}\text { Plaque } \\
(n=3) \\
\text { Laser }(n=1)\end{array}$ & 1 & +0.3 & +2.7 \\
\hline $\begin{array}{l}\text { Sheidow et } \\
\text { al CJO Aug } \\
2002\end{array}$ & $\begin{array}{l}\text { Case } \\
\text { report }\end{array}$ & 1 & Subfoveal & 5 & Standard PDT & & 2 & +0.3 & -3.8 \\
\hline $\begin{array}{l}\text { Robertson } \\
\text { DM Arch } \\
\text { Ophthalmo } \\
\text { I Sep } 2002\end{array}$ & $\begin{array}{l}\text { Case } \\
\text { series }\end{array}$ & 3 & $\begin{array}{l}\text { Juxtapapillary } \\
(n=3)\end{array}$ & $11-14$ & Standard PDT & & 1 & +0.5 & -3.0 \\
\hline $\begin{array}{l}\text { Madreperla } \\
\text { et al Arch }\end{array}$ & $\begin{array}{l}\text { Case } \\
\text { series }\end{array}$ & 3 & $\begin{array}{l}\text { Juxtafoveal }(n=1) \\
\text { Subfoveal }(n=1)\end{array}$ & $3-9$ & Standard PDT & Laser $(n=1)$ & 1 & +0.4 & -2.0 \\
\hline
\end{tabular}


CHOROIDAL HEMANGIOMA TREATMENT

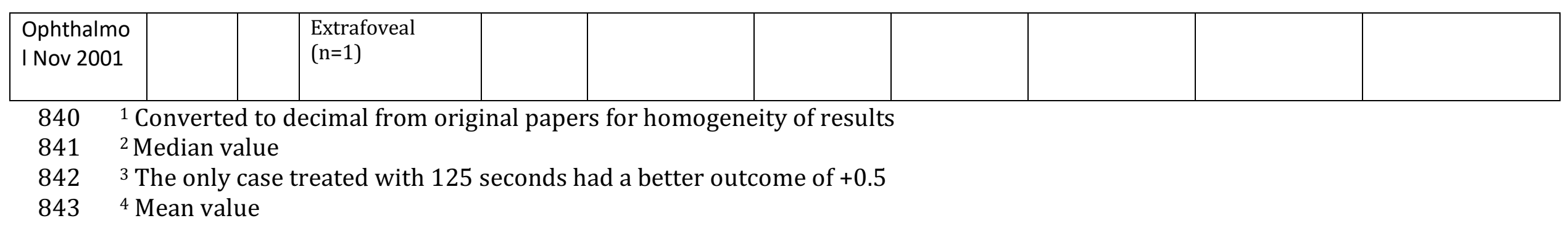


